\title{
Mid-Holocene and historical palaeoecology of the Albufera de València coastal lagoon
}

\author{
Marco-Barba, J. ${ }^{1}$, Burjachs, F.2,3,4, Reed, J.M. ${ }^{5}$, Santisteban, C. ${ }^{6}$, Usera, J.M. ${ }^{6}$, Alberola, C. ${ }^{6}$, \\ Expósito, I. ${ }^{3,4}$, Guillem, J.6, Patchett, F.5, Vicente, E. ${ }^{1}$, Mesquita-Joanes, F. ${ }^{*}{ }^{*}$ and Miracle, M.R. ${ }^{\dagger}$ \\ ${ }^{1}$ Cavanilles Institute of Biodiversity and Evolutionary Biology, University of Valencia. Catedrático José Beltrán \\ Martínez, 2. 46980 Paterna, Spain. \\ 2 ICREA, Pg. Lluís Companys 23, 08010 Barcelona, Catalonia, Spain. \\ 3 IPHES, Institute of Human Palaeoecology and Social Evolution. Campus Sescelades URV, edifici W3. 43007 \\ Tarragona, Catalonia, Spain. \\ ${ }^{4}$ URV, University Rovira i Virgili, Àrea de Prehistòria. Av. de Catalunya 35. 43002 Tarragona, Catalonia, Spain. \\ 5 Dept. of Geography and Geology, School of Environmental Sciences, University of Hull. HU6 7RX King- \\ ston-upon-Hull, UK. \\ ${ }^{6}$ Dep. of Botany and Geology, University of Valencia. Av. Dr. Moliner, 50. 46100 Burjassot, Spain. \\ $\dagger$ University of Valencia (deceased). \\ * Corresponding author: mezquita@uv.es
}

Received: 13/02/18 Accepted: 17/09/18

\begin{abstract}
Mid-Holocene and historical palaeoecology of the Albufera de València coastal lagoon

The Albufera de València coastal lagoon is one of the largest oligohaline lagoons in the Iberian Peninsula. Highly polluted and threatened by plans for urban development, it has been protected as a Natural Park since 1986 to preserve its environment and surroundings, mostly consisting of ricefields and a forested coastal sand bar. Restoration plans focus on recovering the water quality and submerged macrophyte cover that occupied most of the lagoon in the 1950's. Until recent studies, little was known about the wetland's palaeoenvironmental history. To improve this knowledge, we analysed the Holocene evolution of the lagoon based on sedimentology, geochemistry and microfossils (foraminifera, diatoms, ostracods and pollen remains) from four cores. Two were collected in the sand bar, and two from the central lagoon. In combination with previous work, our new data show that the lagoon remained brackish for most of its history since $8700 \mathrm{cal} \mathrm{BP}$, with the frequent presence of accompanying freshwater taxa from 7000 to $3400 \mathrm{cal} \mathrm{BP}$. Notwithstanding chronological uncertainties, some episodes of decline in the abundance of microfossils seem to match aridity events Bond 5 (8.2 ky BP) and Minorca 7 (7.5-7.2 ky BP), the latter marking the switch from a dominance of arboreal vegetation to grasses. The most important change in the water body consisted of a sharp change at the beginning of the $19^{\text {th }}$ century from a brackish to an oligohaline lagoon, driven by anthropogenic hydrological control associated with the expansion of ricefields. Later on, by the 1960-1970's, the growing population impacts of agricultural, wastewater and industrial effluents launched a major eutrophication process that would eventually sharply reduce the benthic vegetation and invertebrate communities and promote the phytoplankton dominance of the ecosystem in a turbid state. Although our multiproxy study has increased understanding of the lagoon's history, somewhat supported by documentary evidence, further palaeoecological research in different parts of the wetland would help define the causes of heterogeneous timing of changes in this large, shallow, complex system. Notwithstanding the need for further research, there is a clear priority for managers and the society to work on restoration efforts to drive the Albufera wetland towards one of the previous, less impacted, states of this worn-out and neglected ecosystem.
\end{abstract}

Key words: Palaeolimnology, pollen analysis, NPP, diatoms, Ostracoda, Foraminifera, isotopes, XRF, climatic events, coastal lagoon evolution, Iberian Peninsula 


\section{RESUMEN}

\section{Paleoecología de la laguna costera de la Albufera de València durante el Holoceno medio y en época histórica}

La laguna costera de la Albufera de València es uno de los mayores lagos oligohalinos de la Península Ibérica. Fuertemente contaminada y amenazada por planeamientos de desarrollo urbanistico, fue finalmente protegida como Parque Natural en 1986, con el fin de preservar la cubeta y sus ambientes aledaños, los cuales consisten fundamentalmente en arrozales y un bosque sobre la barra arenosa costera. Los planes de restauración se centran en recuperar la calidad del agua y la cobertura de macrófitos sumergidos que ocupaban la mayor parte de la laguna en los años 50. Hasta la publicación de algunos trabajos recientes, se conocía bien poco de la historia paleoambiental esta zona húmeda. Con el fin de mejorar esta falta de conocimiento, estudiamos la evolución de la laguna durante el Holoceno mediante análisis sedimentológicos, geoquímicos y de microfósiles (foraminiferos, diatomeas, ostrácodos y restos polínicos) de cuatro registros. Dos de ellos fueron obtenidos en la barra arenosa, y otros dos del centro del lago. En combinación con trabajos anteriores, nuestros nuevos resultados muestran que la laguna permaneció como un ambiente salobre durante la mayor parte de su historia desde 8700 cal BP, con presencia frecuente de taxones dulceacuicolas acompañantes entre los 7000 y 3400 cal BP. A pesar de la incerteza de la cronología, se observan algunos episodios de reducción de abundancia de microfósiles acuáticos que parecen corresponderse con los eventos de aridez Bond 5 (8.2 ky BP) y Menorca 7 (7.5-7.2 ky BP), este último coincidiendo con un cambio notable de dominancia de vegetación arbórea a herbácea. El cambio mayor en el sistema acuático consistió en una transformación drástica a principios del s. XIX de una laguna salobre a una oligohalina, producida por un control antropogénico de la hidrología, asociado a la expansión del cultivo del arroz. Más tarde, entre 1960 y 1970 aproximadamente, el incremento poblacional y los impactos asociados de la agricultura, las aguas residuales y los efluentes industriales provocaron un proceso extraordinario de eutrofización que conllevaría una fuerte reducción de la vegetación sumergida y las comunidades de invertebrados, promoviendo la dominancia del fitoplancton de un sistema que pasó a un estado de alta turbidez. Aunque nuestro estudio con múltiples indicadores haya aumentado nuestro conocimiento de la historia de la laguna, con la ayuda de evidencias documentales, un mayor esfuerzo de investigación paleoecológica en diferentes zonas del humedal ayudaría a definir las causas de una dinámica temporal heterogénea en este extenso y complejo humedal. A pesar de esta necesidad de nuevas investigaciones, actualmente existe una prioridad para los gestores y la sociedad, de trabajar en esfuerzos de restauración que lleven a la zona húmeda de la Albufera hacia uno de los estados previos menos impactados de este ecosistema ampliamente sobreexplotado y desatendido.

Palabras clave: Paleolimnología, análisis polínico, palinomorfos no polínicos, diatomeas, Ostracoda, Foraminifera, isótopos, $X R F$, eventos climáticos, evolución de lagunas costeras, península ibérica

\section{INTRODUCTION}

\author{
"València té els matins lluents, \\ pel sol que juga amb el mar \\ i corre per l'Albufera" \\ Al-Russafí de València (12 th century) \\ version by J. Piera (1983)
}

As poets have sung for centuries, the Albufera lagoon is recognized as a keystone symbol of landscape beauty in the area of València and, in modern parlance, is of very high value as an 'ecosystem service' in the semi-arid Mediterranean climate. As a scarce and valuable water resource, it has long been threatened by intensive agricultural, industrial and demographic development, however, which has ultimately had a severe impact on the aquatic ecosystem and its surrounding catchment. Its current status is one of a highly polluted and artificially-regulated water body, mostly used as a dam for ricefield irrigation and as a deposit for sewage outflow (Vicente \& Miracle, 1992; Soria, 2006). An urban development plan designed in the 1960's for the transformation of a forested area on the sand bar between the lagoon and the sea caused widespread environmental protest and resulted in the designation of the wetland ecosystem as a Natural Park in 1986 (Fundació d'Amics del Parc Natural de L'Albufera, 2000). In spite of this, the sad story of the ongoing process of eutrophication and degradation of water quality, and recent attempts at restoration, are well documented (Soria, 2006, Miracle et al., 2012). Knowledge of a lagoon's pre-impact state is essential for effective restoration, but almost no data are available either on limnology or landscape biodiversity prior to the first quarter of the $20^{\text {th }}$ century, particularly for ages previous to the publication of the work by Cavanilles (1795). 
What was the origin of the lagoon? What was the impact of the marine transgression following the Pleistocene-Holocene climatic transition? Was its (pre-) historical limnology similar to observations of the first half of the 20th century by Pardo (1942)? Archaeological and historical sources point to a very long history of human occupation around the Albufera wetland system, with extensive resource exploitation, providing evidence which suggests growing impacts since early prehistorical times up to drastic habitat modification and desiccation of large areas of the lake during the past few centuries (Mateu et al., 1985; Rosselló i Verger, 1995; Sanchis Ibor, 2001).

The first palaeolimnological work in the lagoon was carried out by Margalef \& Mir (1973), who found diatom-based evidence for a marked salinity decrease in the top $20 \mathrm{~cm}$ of two short cores. Similar differences between surface and deeper (up to $85 \mathrm{~cm}$ ) sediment samples from the bottom of the lagoon were also found when analysing the malacological composition (Robles et al., 1985), with a remarkable abundance of the lagoon cockle Cerastoderma glaucum (Bruguière, 1789) in the deeper zones of the three short cores extracted. These authors conclude that the lagoon was previously brackish, in contrast to the present-day freshwater (oligohaline) state. Considering the scarcity of palaeoecological studies since these works (but see recent research by Carmona et al., 2016), and keen to understand the evolution of the wetland ecosystem, the senior author (MRM) of the present text launched a multi-proxy project in 2002. From this effort, papers have been published on the stratigraphy and evolution of the Albufera, mostly based on ostracod remains (Santisteban et al., 2009; Marco-Barba et al., 2012; 2013a; b), but much information remains unpublished. In this paper we strengthen previous inferences by incorporating additional proxy data for the history of the lagoon and its catchment, including pollen, foraminifera and diatoms. These new proxy data support and build up on the palaeohydrological interpretations previously provided only by lithology and Ostracoda remains from two littoral cores and, most importantly, also add new landscape palaeoenvironmental reconstructions based on pollen analysis, since the end of the early
Holocene. A new core from the centre of the lake is thoroughly analysed using high resolution XRF analysis and ostracod community and geochemical data to compare it with previous records from other areas of the lake and therefore contribute to unveil the spatial coordinated or heterogeneous response of the lake to human impacts and environmental changes. Furthermore, the new core expands the time period previously analysed for a shorter core (which encompassed from the 18th to $20^{\text {th }}$ century), providing a wider time window down to earlier Middle Ages.

Previously, the origin of the lagoon was thought to date to the maximum marine Holocene transgression at c. 6000 y BP (Mateu et al., 1985; Ruíz \& Carmona, 2005), but our results to date (Santisteban et al., 2009; Marco-Barba et al., 2013a), and those of recent publications (Carmona et al.., 2016), suggest that a brackish wetland was already present by 8700 cal. BP, whose enclosing sandbar was probably located to the east of the present-day coastline. This earlier origin is somehow in agreement with the ontogeny of other active coastal lagoons since c. 8000 BP in Southern France (Mateu et al., 1985). Other coastal lagoons appeared since at least $7400 \mathrm{BP}$ in the south of the Iberian Peninsula (Almeria; Goy et al., 2003), or since 7500-7600 cal. BP in the nearby sites of Elx (Blázquez \& Usera, 2010) and Almenara, with a previous brackish marsh in Almenara during the earlier drier period (Blázquez et al., 2017). Furthermore, the Mesolithic remains of Cerastoderma glaucum (not dated but considered older than $7000 \mathrm{BP}$ ) found in the adjacent hills to the west of the present Albufera de València (Mateu et al., 1985) also support such early origin. It is difficult to say to what extent prehistoric societies might have modified the landscape, other than hunting and gathering for food. Palaeopalynological records from other Mediterranean coastal areas of the Iberian Peninsula suggest evidence for anthropic effects as early as the Boreal period (8000-9000 y BP), and presence of Olea and Vitis, added to inland deforestation during the following millennium (López-Sáez \& López-García, 1999). Later, at c. 7500 cal. BP, the archaeological remains in the region indicate the beginning of the Neolithic agricultural and pastoral practices (Bernabeu et 
al., 2014, Bernabeu-Aubán et al., 2016). Recent, historical human impacts on the landscape and the limnology of the lagoon have been severe, but it might be possible that they started long ago. Here we try to unveil part of the long history of the lagoon and infer climatic and human effects on its long-term dynamics.

\section{METHODS}

\section{Study area}

The Albufera de València (Fig. 1) is one of the largest oligohaline lagoons of the Iberian Peninsula. It has an area of $2320 \mathrm{Ha}$ with a mean depth
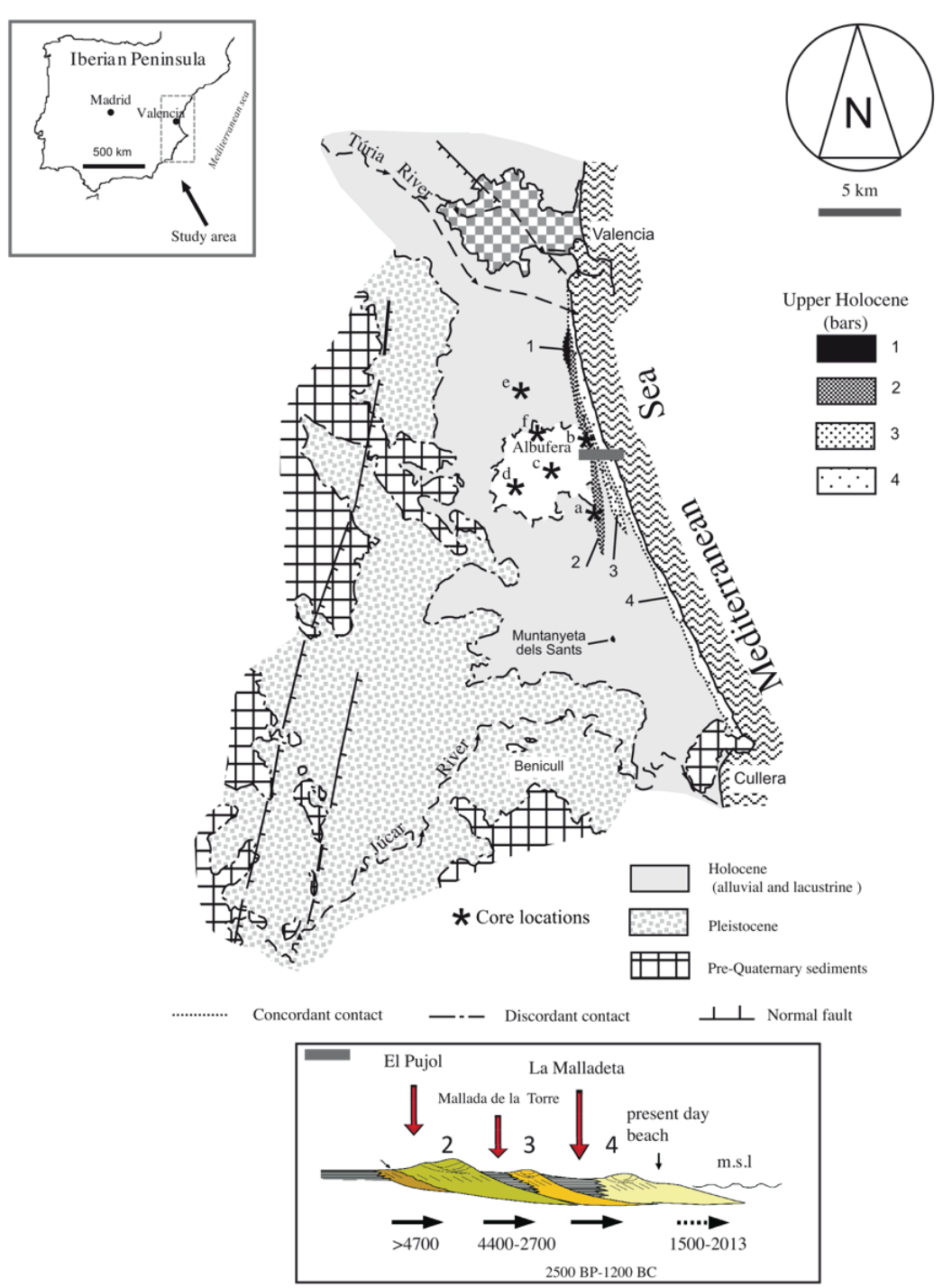

Figure 1. Geological and lithological composition of the studied area in Albufera de València, showing the location of the cores analysed or discussed in the text. A lithological transversal cut of the sand bar is also shown (after Santisteban et al, 2009). Core locations: a, Core Palmar; b, Core Pujol; c, Core Centre; d, Core Antina; e, core in Carmona et al. (2016); f, core in Rodrigo et al (2010). Composición geológica y litológica del área de estudio en la Albufera de València, así como localización de los registros estudiados o discutidos en el texto. Se muestra también un corte transversal de la barra arenosa (a partir de Santisteban et al., 2009). Localizaciones de los registros: a, Core Palmar; b, Core Pujol; c, Core Centre; d, Core Antina; e, registro en Carmona et al. (2016); f, registro en Rodrigo et al. (2010). 
of $1 \mathrm{~m}$, separated from the sea by a sand bar $(\approx 1$ $\mathrm{km}$ wide). It is enclosed on the Quaternary floodplain lying between the alluvial fans of Túria (North) and Xúquer/Júcar (South) rivers. These rivers drain the southeastern sector of the Iberian Mountain System (mostly composed of Cretaceous and Jurassic limestones); the precipitation regime is characterized by a marked seasonal pattern, such that peak flash floods may reach $3000 \mathrm{~m}^{3 / \mathrm{s}}$. Although the fluvial hydrology is modified by various dams, the rivers retain the capacity to transport gravels, silt and clay sediment to the lower reaches. The Túria River sediment load contributed to the formation during the Holocene of the sand bar that protects the Albufera from the sea (Carmona \& Ruiz, 1999). The sediments are transported by coastal drift currents towards the south and deposited by wave action during seasonal eastern storms. According to Santisteban et al. (2009), the sand bar is composed of four prograding units (Fig. 1). The oldest one (pre-4700 y BP) is moderately eroded. The second and the third have the configuration of spit beaches developed at the southernmost part of the Holocene Túria delta, and the last unit was formed in historical times.

Climatic and climate-driven events such as sea-level change, storm events and river floods have affected the Albufera's hydrology, ecology, water chemistry composition and landscape throughout its history. With accelerated impacts likely to have been initiated by the development of irrigated rice paddies and commercial and population expansion during the Industrial Revolution (towards the mid 19th century), the Albufera de València is currently a hypereutrophic and highly polluted lagoon (Vicente \& Miracle, 1992; Marco-Barba et al., 2013a,b).

\section{Core material and dating}

Four sediment cores were extracted from the Albufera lagoon (Fig. 1). Two long sequences were collected in the sand bar: El Palmar, $18.5 \mathrm{~m}$ long, and Pujol, $16 \mathrm{~m}$ long. The extraction methods, lithology and ostracod palaeoecology and chronology for the El Palmar core are described by Santisteban et al. (2009) and Marco-Barba et al. (2013a), encompassing a period from 8700 to 3400 cal y BP. The same methods of extraction and ostracod analysis apply to core Pujol, and these and its lithological description, in relation to core El Palmar are also included in Santisteban et al. (2009). Unfortunately, no radiocarbon dates are available for core Pujol, but Santisteban et al. (2009) provide a stratigraphical correlation with core El Palmar. The remaining two, shorter, cores were extracted from the inundated central part of

Table 1. Radiocarbon dates obtained for Core Centre, and material and laboratory details. The last two columns indicate the estimated (est.) calendar years from sediment accumulation rates and other proxies (historic data, magnetic susceptibility and XRF analysis), and the corresponding reservoir effect $(\mathrm{R}(\mathrm{t})$ ) calculated from the estimated dates. See text for further explanations. Dataciones de radiocarbono obtenidas del core Centre, y detalles del material y del laboratorio de análisis. Las últimas dos columnas indican la edad en años calendario estimada (est.) a partir de las tasas de acumulación del sedimento y otros indicadores (datos históricos, susceptibilidad magnética y análisis XRF), así como el efecto reservorio $(R(t))$ correspondiente, calculado a partir de las fechas estimadas. Véase el texto para mayor explicación.

\begin{tabular}{cccccccc}
\hline $\begin{array}{c}\text { Depth } \\
(\mathbf{c m})\end{array}$ & $\begin{array}{c}{ }^{14} \mathbf{C} \text { date } \\
\text { (uncal. yr BP) }\end{array}$ & $\begin{array}{c}{ }^{14} \mathbf{C} \text { date } \\
\text { (cal. yr BP) }\end{array}$ & Material & Laboratory & $\begin{array}{c}\text { Lab. } \\
\text { Code }\end{array}$ & $\begin{array}{c}\text { Est. date } \\
\text { (cal. yr AD) }\end{array}$ & $\begin{array}{c}\mathbf{R}(\mathbf{t}) \\
(\mathbf{y r})\end{array}$ \\
\hline 89 & $1460 \pm 30$ & $995 \pm 65$ & shell & Beta Analytic & 313444 & 1772 & 817 \\
94 & $1340 \pm 30$ & $875 \pm 55$ & shell & Beta Analytic & 313445 & 1744 & 669 \\
135 & $2655 \pm 30$ & $2794 \pm 55$ & pollen & Poznań Radioc. Lab. Poz-19788 & 1450 & 2294 \\
140 & $2400 \pm 30$ & $2030 \pm 80$ & shell & Beta Analytic & 313446 & 1400 & 1480 \\
225 & $3090 \pm 30$ & $2850 \pm 80$ & shell & Beta Analytic & 313447 & 550 & 1450 \\
229 & $3520 \pm 35$ & $3789 \pm 100$ & pollen & Poznań Radioc. Lab. Poz-18865 & 510 & 2349 \\
233 & $22260 \pm 140$ & $22265 \pm 285$ & pollen & Poznań Radioc. Lab. Poz-18288 & 470 & n.d. \\
\hline
\end{tabular}


the lagoon. The lithology, chronology, ostracod palaeoassemblages and geochemistry of the shortest ( $63 \mathrm{~cm}$ long encompassing the early $18^{\text {th }}$ to the end of the 20th century) core Antina were presented by Marco-Barba et al. (2013b). Finally, a 240 $\mathrm{cm}$ core (Core Centre) was taken in July 2006 from a point in the middle of Albufera de València (UTM: 30S728065/4357504; Fig. 1). It was extracted using a Livingstone corer with $8 \mathrm{~cm}$ diameter inner liner and kept in a polyethylene tube. The core was analysed at $0.5 \mathrm{~cm}$ resolution for magnetic susceptibility (MS) with a GEOTEK core logger at the Limnological Research Center (LRC) of the University of Minnesota (USA), and was then subdivided in two halves. One half was used for imaging (DMT core scanner) colour, grain-size descriptions and ITRAX XRF core scanning; the other half was sampled for fossil content and geochemical analysis.

For Core Centre, seven radiocarbon dates (Table 1) were obtained from mollusc shells (Cerastoderma glaucum) and pollen concentrates selected from subsamples with high organic matter content. The radiocarbon measurement ('BP') was calibrated to calendar years ('cal.BP') using OxCal v3.10 software, with the Intcal04 curve for pollen and the Marine0 4 curve for shells (Hughen et al., 2004; Reimer et al., 2004; Bronk Ramsey, 2005) and later corrected for the reservoir effect in aquatic environments (see details in the results section). To determine age and sediment accumulation rates for the past 200 years a twin short $(1 \mathrm{~m})$ gravity core was extracted in the same location for $210 \mathrm{~Pb}-137 \mathrm{Cs}$ dating. $210 \mathrm{~Pb}$ was measured at $4-6 \mathrm{~cm}$ depth intervals by means of its granddaughter product 210Po (Eakins $\&$ Morrison, 1976). Activity was measured for 1-6 $\times 10^{5} \mathrm{~s}$ with ion-implanted surface barrier detectors and an Ortec alpha spectroscopy system. The ${ }^{137} \mathrm{Cs}$ values were confirmed by gamma spectrometry on an EG\&G Nuclear ultra-low background well detector. All dating analyses were performed at Minnesota's St. Croix Watershed Research Station. Unsupported $210 \mathrm{~Pb}$ was calculated by subtracting supported activity from the total activity measured at each level; supported $210 \mathrm{~Pb}$ was estimated from the asymptotic activity at depth (the mean of the lowermost samples in the core). Dates and sedimentation rates were determined according to the cf:cs. (constant flux: constant sedimentation model, Appleby and Oldfield, 1978) with confidence intervals calculated by first-order error analysis of counting uncertainty (Binford, 1990).

\section{XRF and geochemical analysis}

The main geochemical elements Al, Si, P, S, Cl, $\mathrm{K}, \mathrm{Ca}, \mathrm{Ti}, \mathrm{V}, \mathrm{Cr}, \mathrm{Mn}, \mathrm{Fe}, \mathrm{Co}, \mathrm{Ni}, \mathrm{Cu}, \mathrm{Zn}, \mathrm{As}, \mathrm{Rb}$, $\mathrm{Sr}, \mathrm{I}, \mathrm{Zr}, \mathrm{Ba}$ and $\mathrm{Pb}$ were analysed every $5 \mathrm{~mm}$ from the bottom to $66 \mathrm{~cm}$ depth and every $2 \mathrm{~mm}$ from $66 \mathrm{~cm}$ to the top of Core Centre on the ITRAX XRF core scanner at the Large Lakes Observatory of the University of Minnesota (Duluth, USA) using $30 \mathrm{sec}$ count time, $30 \mathrm{kV}$ X-ray voltage and an X-ray current of $20 \mathrm{~mA}$. The obtained values are given as counts per second, although high correlations have been found between ICP-OES and XRF-scanner data for some elements in different studies (Boyle, 2000; Moreno et al., 2010). The XRF results for each element were transformed to arcsine of the square root of proportions; the data matrix was analysed by means of PCA (Principal Components Analysis).

The subdivision of Core Centre was carried out at approximately $2 \mathrm{~cm}$ intervals for the bottom metre and every $1 \mathrm{~cm}$ (high resolution) in the upper metre. In total, 72 samples were obtained for different analysis (geochemistry, mineralogy and micropalaeontological studies). Aliquot subsamples (between 0.3-0.7 g) were weighed, dried at $105{ }^{\circ} \mathrm{C}$ during $2 \mathrm{~h}$ and weighed again to determine water content and dry weight per gram of fresh sample. The remaining sediment was heated at $460{ }^{\circ} \mathrm{C}$ for $7.5 \mathrm{~h}$ to determine organic matter content (loss on ignition; LOI) and subsequently at $950{ }^{\circ} \mathrm{C}$ for $8 \mathrm{~h}$ to obtain the concentration of carbonates per sample, calculated from $\mathrm{CO}_{2}$ loss (Heiri et al., 2001). Subsamples were also taken to measure total nitrogen (TN) and phosphorus (TP) content. Samples were digested according to Valderrama (1981) modified for sediments. All samples were also submitted to a conventional digestion procedure with sulphuric acid and potassium persulphate for phosphorus analysis (APHA, 1992; Ferree \& Shannon, 2001). 


\section{Diatom analysis}

To assess limnological variation in the littoral and profundal zone, and for comparison with vegetation history, the El Palmar (long edge core) and lagoon centre (Antina) sequences were selected for analysis. Diatoms were prepared using standard techniques (Battarbee et al., 2001), mounting slides with $\operatorname{Naphrax}^{\circledR}$. Where diatoms were preserved, El Palmar samples were counted initially at ca. $10-12 \mathrm{~cm}$ resolution and at higher resolution $(\min .3 \mathrm{~cm})$ in zones of good preservation, comprising 65 samples. A full count $(>500$ valves) was possible in 12 subsamples and diatom species presence was noted for a further 8 samples in which diatoms were rare. A full count was possible in 13 samples prepared at approximately $4 \mathrm{~cm}$ resolution (range $2-8 \mathrm{~cm}$ ) in the upper $53 \mathrm{~cm}$ of the Antina sequence, with rare preservation below. Diatoms were identified using Krammer \& Lange-Bertalot (1986, 1988, 1991a and 1991b), adopting updated diatom nomenclature. Counts were converted to percentage data and displayed using Tilia (Grimm, 1991-2015). Zone boundaries were defined using constrained incremental sum of squares analysis (CONISS; Grimm, 1987). Diatom-conductivity reconstruction was carried out based on the European Diatom Database Combined Salinity training set (Battarbee et al., 2000), using weighted averaging with inverse deshrinking in the programme C2 (Juggins, 2007), and data from this and the Spanish diatom-conductivity training set (Reed, 1998) were used to aid interpretation. The abundance of fragilarioid taxa (facultative planktonic group), which have very broad ecological tolerance ranges, is problematic for quantitative reconstruction, so these taxa were omitted in application of the transfer function to El Palmar.

\section{Foraminifera analysis}

Foraminifera remains were analysed from a total of 62 samples from El Palmar core, 64 samples from Pujol, 12 samples from the Antina sequence and 49 samples from Core Centre. Sediment samples were air dried and then submersed in warm water to separate the organic matter from foraminifera. No other chemical products were used, to avoid damaging agglutinated foraminiferal shells, which are common in lagoonal environments. Samples were then sieved under a smooth water flow using a $62 \mu \mathrm{m}$ mesh. The remains were dried prior to analysis under the stereomicroscope. A minimum number of 300 individuals per sample were picked for species determination and counting. The data were analysed for diversity changes over time using the effective number of species approach (Jost, 2006), by means of diversity of order 0 ( $\mathrm{S}=$ species richness) and order $1(\mathrm{eH}=$ exponential of Shannon diversity using natural logarithms).

\section{Ostracod analysis}

Subsamples from core Centre were processed for ostracod analysis using a modified version of Griffiths \& Holmes (2000), and explained in detail in Marco-Barba et al. (2013a,b) for cores El Palmar and Antina. Similarly, for Core Centre, between 10 and $15 \mathrm{~g}$ of wet sediment were weighed, air dried and then wet-sieved for 30 minutes through 400 and $250 \mu \mathrm{m}$ pore size meshes. Species were identified following mostly Athersuch et al. (1989), Meisch (2000) and Poquet et al. (2008). We noted the states of preservation (SP) of shells as described in Marco-Barba et al. (2013a). Only valves belonging to good preservation states (A and B) were included in multivariate analysis (see below).

Between 1 and 137 Cyprideis torosa adults per sample (adult females and males) were measured for carapace length, as this is known to potentially vary with salinity (Mezquita et al., 2000). The percentage of noded animals per sample (van Harten, 1975; Marco-Barba, 2013a) was also calculated to assess salinity variation (Vesper, 1972a,b; van Harten, 1975; Marco, 2010; Frenzel et al., 2012; Marco-Barba et al., 2013a).

Between four and $20 C$. torosa valves were analysed per sample of Core Centre for shell oxygen and carbon isotopic variation. Analyses were performed on single adult valves by preference; in the absence of these, juveniles of late growth instars (A-1 and A-2) were pooled in groups of 4 or 5 valves. Adults and juveniles, and males and females, were analysed separately. 
Between two and 10 analyses were carried out per sample to determine the valve calcite isotopic ratios $18 \mathrm{O} / 16 \mathrm{O}$ and $13 \mathrm{C} / 12 \mathrm{C}$. Ostracod valves were cleaned for geochemical analysis using the method described in Ito (2001). Cleaned valves were analysed mostly using a Kiel-II online carbonate preparation device coupled to a Finnigan MAT 252 stable isotope ratio mass spectrometer (University of Minnesota) and a few samples (60 samples $\approx 159$ valves) using a MAT 251 (Michigan) mass spectrometer, both connected to a Kiel carbonate preparation device. Analytical precision was typically $<0.1 \%$ for both $\delta^{13} \mathrm{C}$ and $\delta 18 \mathrm{O}$. Samples were run from the same levels in the two different labs to ensure that the different analytical protocols did not affect the results.

The number of valves per $10 \mathrm{~g}$ of dry sample ( $\mathrm{N}=70$ samples) was $\log$ transformed ( $\log _{10}$ (number of valves +1 )) for ostracod stratigraphical analysis. A constrained cluster analysis was performed applying the CONISS method and the Edwards \& Cavalli-Sforza distance (Grimm, 1987). The whole transformed data matrix was ordered with PCA.

Correlations between $C$. torosa shell lengths and isotope ratios $\left(\delta^{18} \mathrm{O}_{\mathrm{vpdb}}\right.$ and $\left.\delta{ }^{13} \mathrm{C}_{\mathrm{vpdb}}\right)$ were performed using either Pearson (when data was normally distributed) or Spearman (for not normally distributed data) correlation techniques. Palaeosalinity reconstruction of lagoon Albufera from Core Centre was carried out using ostracod-based weighed averaging transfer functions based on the species' optima and tolerances as detailed in Marco-Barba et al. (2013b).

\section{Palynological analysis}

To provide a long record of vegetation history, with high resolution analysis of recent change, pollen analysis was carried out in two selected sequences - the long core, El Palmar, and the short central core, Antina. Subsamples were selected to span the range of lithological zones in El Palmar (62 samples) and at $1 \mathrm{~cm}$ resolution (53 samples) in Antina. The preparation of pollen, non-pollen palynomorphs (NPPs) and palynological microcharcoal samples followed standard methods outlined in Goeury \& Beaulieu (1979) but adapted by Burjachs et al. (2003). The sediments were reduced by $\mathrm{HCl}$, humic acids washed in $\mathrm{NaOH}$, floated in dense Thoulet liquor, and filtered with a glass fibre filter which was subsequently destroyed with $70 \%$ HF. All steps were followed by washing and centrifuging with distilled water. The final residue of each sample was mounted in preparation for biological microscopy diluted with glycerin. Circa 150-500 pollen grains of terrestrial taxa were counted using an Olympus CX41 microscope fitted with x15 oculars and x40/60 objectives. For El Palmar, results are presented for 33 samples in which a representative count was possible; pollen preservation was poor in the remaining 29 samples.

Cyperaceae, Typha/Sparganium, Polygonum t. persicaria, Ruppia, Potamogeton, Myriophyllum and Lemna-type have been excluded from the pollen sum to avoid overrepresentation by local littoral taxa. All pollen types are defined according to Moore et al. (1991), Reille (1992, 1995, 1998), Beug (2015) and Cerealia-type was defined according to the morphometric criteria of Andersen (1978), Faegri \& Iversen (1989) and Tweddle et al. (2005). Non-pollen palynomorph (NPP) identification followed van Geel (1978, 2001), van Hoeve \& Hendrikse (1988) and Revelles et al. (2016). To calculate the percentages of NPPs an independent basic sum of the pollens has been made. Pollen concentration (PC) is expressed in pollen grains/g of dry sediment following the volumetric method (Loublier, 1978). Pollen and NPPs were compiled and plotted using Tilia (Grimm, 1991-2015). Pollen and NPPs zones were established using the stratigraphically constrained square root transformation (CONISS) (Grimm, 1987).

\section{RESULTS}

\section{Cores El Palmar and Pujol}

The long, littoral sedimentary sequences of Palmar and Pujol were described by Santisteban et al. (2009). Further information on the chronology, ostracod palaeoecology, geochemistry and palaeoenvironmental interpretation of El Palmar was provided by Marco-Barba et al. (2013a). Usera et al. (1990; 1995; 2006; 2007a,b) and Usera \& Alberola (2011) also provide brief notes 


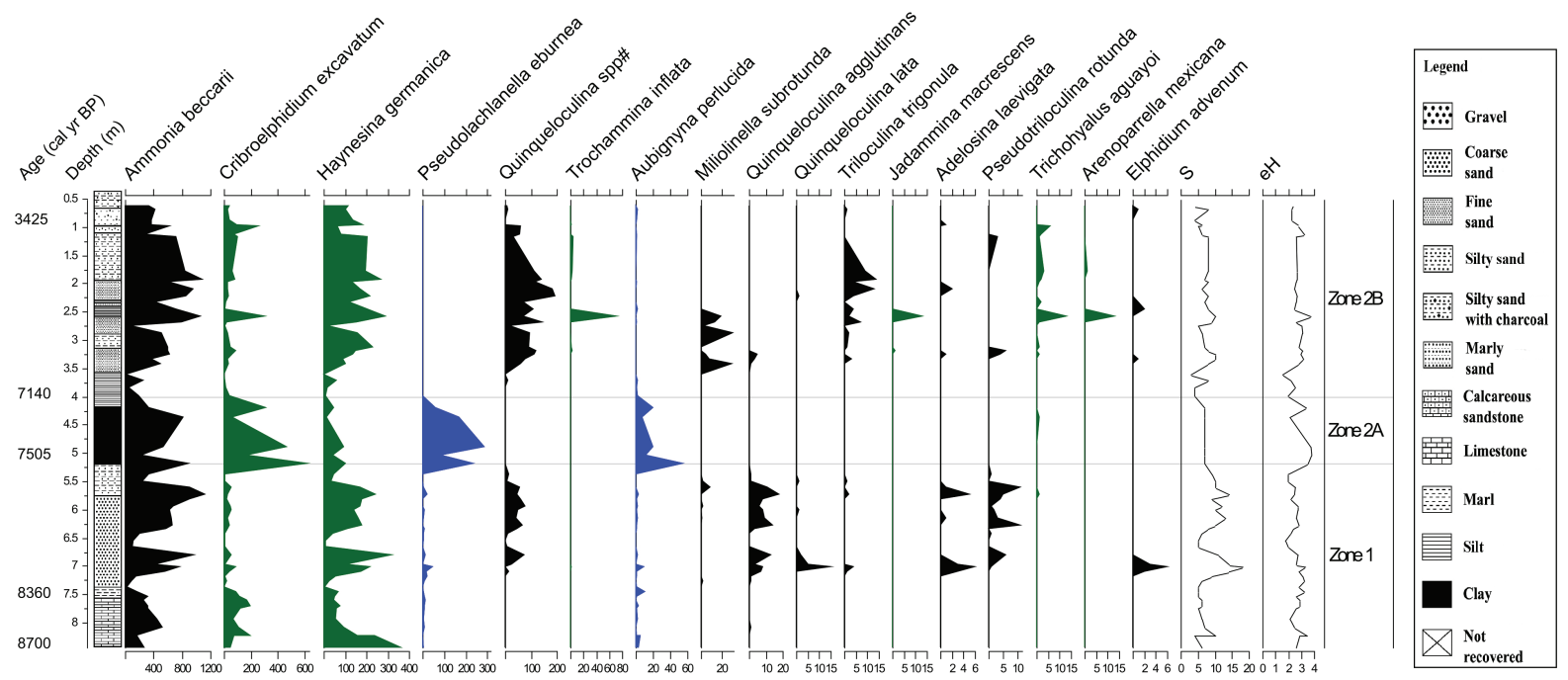

Figure 2. Summary stratigraphic diagram of foraminifera abundances in Lake Albufera core Palmar showing taxa present at minimum $>5$ individuals. Green: species tolerant of relatively low salinity in brackish waters (other than Ammonia spp.); blue: those considered less tolerant to low salinity. The diversity of order $0(\mathrm{~S}=$ species richness $)$ and order $1(\mathrm{e} H$, where $\mathrm{H}=\mathrm{Shannon}$ diversity), and zone boundaries defined by constrained cluster analysis are shown on the right. Gráfico estratigráfico resumen de los foraminiferos del core Palmar de la laguna de la Albufera, mostrando las especies con un mínimo de individuos $>$ 5. Verde: especies tolerantes a salinidades relativamente bajas en aguas salobres (aparte de Ammonia spp.); azul: aquellas poco tolerantes a bajas salinidades. A la derecha se muestran la diversidad de orden 0 ( $S=$ riqueza de especies) y orden 1 ( $\mathrm{H}$, donde $H=$ diversidad de Shannon), así como las zonas definidas mediante análisis constreñido de clasificación.

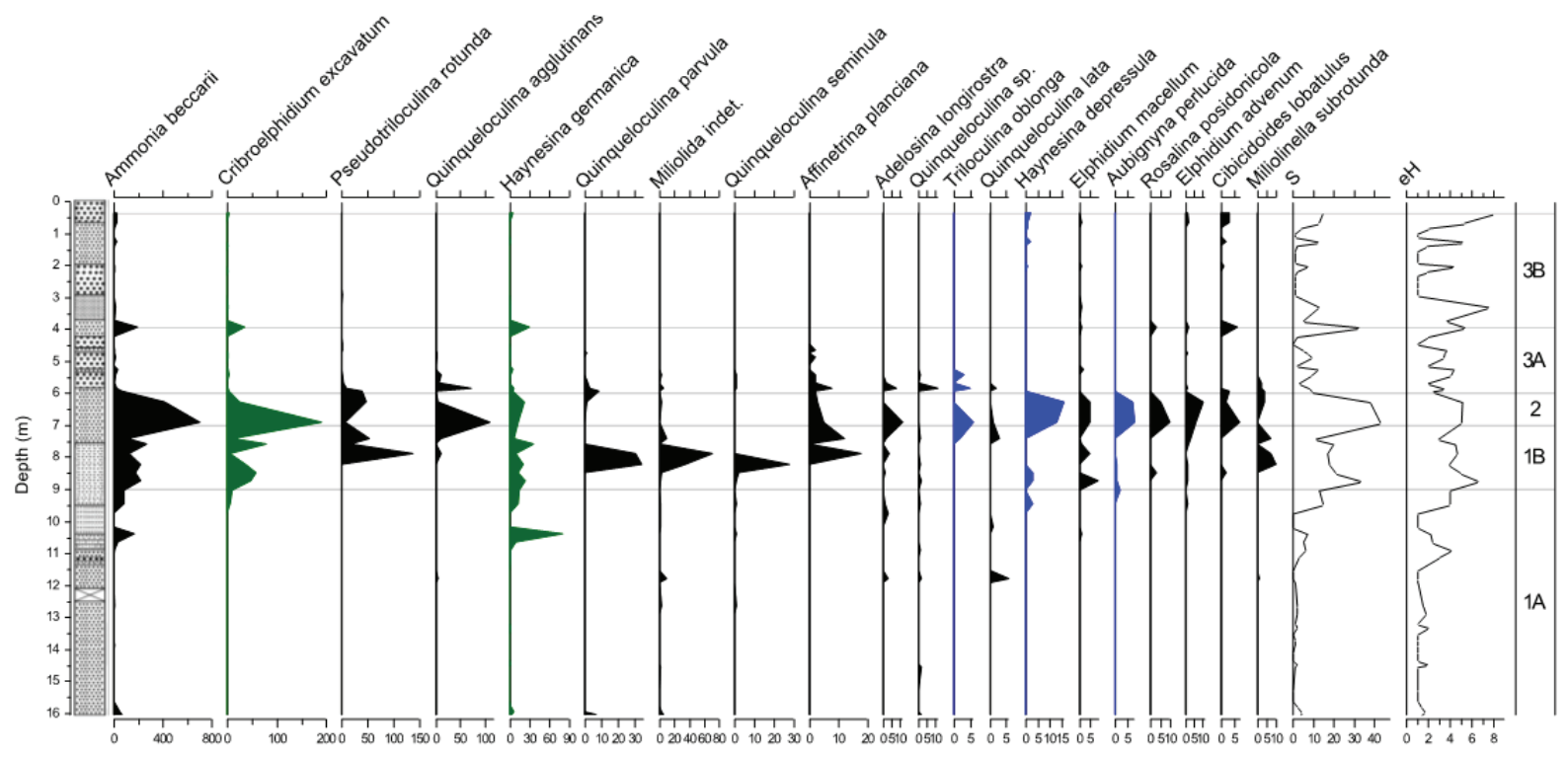

Figure 3. Summary stratigraphic diagram of foraminifera abundances in Lake Albufera core Pujol showing taxa present at minimum $>5$ individuals. Green: species tolerant of relatively low salinity in brackish waters (other than Ammonia spp.); blue: those considered less tolerant to low salinity. The diversity of order $0(\mathrm{~S}=$ species richness) and order $1(\mathrm{e} H$, where $\mathrm{H}=$ Shannon diversity), and zone boundaries defined by constrained cluster analysis are shown on the right. Sediment legend as in figure 2. Gráfico estratigráfico resumen de los foraminiferos del core Pujol de la laguna de la Albufera, mostrando las especies con un mínimo de individuos $>5$. Verde: especies tolerantes a salinidades relativamente bajas en aguas salobres (aparte de Ammonia spp.); azul: aquellas poco tolerantes a bajas salinidades. A la derecha se muestran la diversidad de orden $0\left(S=\right.$ riqueza de especies) y orden 1 ( $e^{H}$, donde $H=$ diversidad de Shannon), así como las zonas definidas mediante análisis constreñido de clasificación. Leyenda de la columna sedimentaria como en la figura 2. 
on the foraminifera of these cores and other parts of the lagoon. Here we incorporate new and extended palaeoecological data from foraminifera, diatom and pollen analysis.

\section{Foraminifera}

A total of 46927 foraminifera were identified from core El Palmar, belonging to 47 species. The most abundant species through the sequence were Ammonia beccarii (Linné, 1758), Cribroelphidium excavatum (Terquem, 1875) and Haynesina germanica (Ehrenberg, 1840) (Fig. 2). Three (sub-)zones could be distinguished based on constrained cluster analysis. Zone 1 (850-520 $\mathrm{cm})$ was rich in species but dominated by the three aforementioned taxa, resulting in relatively low $\mathrm{eH}^{\mathrm{H}}$ diversity values. The base of zone 2 (subzone 2A, $520-400 \mathrm{~cm}$ ) shows a marked change in species dominance, with reduced species richness (S) but important peaks of C. excavatum, Pseudolachlanella eburnea (d'Orbigny, 1839) and Aubignyna perlucida (Heron-Allen \& Earland, 1913), promoting increased evenness and consequently high ecological diversity of order one $\left(\mathrm{e}^{\mathrm{H}}\right)$. The upper subzone (subzone $2 \mathrm{~B}$, $400-50 \mathrm{~cm}$ ) shows again relatively high and constant $\mathrm{S}$ and $\mathrm{e}^{\mathrm{H}}$ values.

In Pujol, the identification of 5744 foraminifera individuals yielded a higher number of species, with a total of 93 different taxa. Again, $A$. beccarii was the dominant species, together with C. excavatum, H. germanica and Pseudotriloculina rotunda (d'Orbigny in Schlumberger, 1893) (Fig. 3). Furthermore, Quinqueloculina agglutinans (d'Orbigny, 1839) is also occasionally abundant. The basal $7 \mathrm{~m}$ (subzone 1A, 1600-900 cm) of the sequence show the lowest diversity, with an increase to higher values in the next subzone (1B; $900-700 \mathrm{~cm}$ depth), corresponding to mud and clay lacustrine deposits during a regressive period (Santisteban et al., 2009). Foraminiferal diversity reaches maximum peaks in the following Zone 2 (700 - $600 \mathrm{~cm}$ depth), during a sandy beach phase in a transgressive period (Santisteban et al., 2009). The upper zone (Zone 3; $600-$ $50 \mathrm{~cm}$ ) is variable in species composition, but shows a return to lower diversity and number of individuals collected, similar to subzone $1 \mathrm{~A}$.

\section{Diatoms}

Diatoms from El Palmar (Fig. 4) are only preserved from $312 \mathrm{~cm}$ to $63 \mathrm{~cm}$ depth, from the mid Holocene onwards. Samples where diatoms were present but too sparse for a full count (99, 112, 178, 209, 269, 274, 288, 319, 326 and 341 $\mathrm{cm}$ depth) all contain robust taxa which are resistant to dissolution, but of a similar character to zones of better preservation. Three diatom zones can be recognised, but the sequence essentially shows little evidence for major limnological change. The sequence is dominated by benthic and facultative planktonic (FP) taxa throughout. Planktonic taxa are rare. The taxa are all common in the modern environment of Spanish saline lakes (Reed et al., 2001) and are mainly those which tolerate slightly brackish (oligosaline) to mesosaline waters. This is reflected in the complacency of the diatom-inferred conductivity (DI-Cond) curve, which fluctuates around the oligo-mesosaline boundary of $3000 \mu \mathrm{S} / \mathrm{cm}$.

Zone $1(341.5-251.5 \mathrm{~cm})$ is dominated by $\mathrm{FP}$ taxa, and Pseudostaurosira brevistriata in particular. A range of benthic taxa, including obligate saline species such as Mastogloia braunii and Amphora coffeaeformis, are present at up to $50 \%$ abundance. Planktonic taxa are present at $<$ $2 \%$. The presence at low abundance of Achnanthidium minutissimum, a freshwater species common in streams, may indicate the influence of freshwater inflow to the lagoon. The uppermost sample exhibits minimum DI-Cond, a sample which is dominated to $80 \%$ by FP taxa.

Zone $2(251.5-209.5 \mathrm{~cm})$ is marked by a reduction in the relative abundance of $P$. brevistriata, accompanied by slight increases in benthic taxa including Navicula veneta. Some obligate saline taxa in the Mastogloia genus decrease in abundance but the continued occurrence of others (A. coffeaeformis, Nitzschia elegantula, etc.) suggests no marked shift in limnology.

Zone $3(209.5-63 \mathrm{~cm})$ is a zone of particularly poor diatom preservation. The zone boundary is again marked by subtle shifts in diatom species assemblage composition, such as a slight increase in obligate, saline Seminavis pusilla. The first presence of plankton at $>2 \%$ abundance at $96 \mathrm{~cm}$ depth is that of a Cyclotella ocel- 


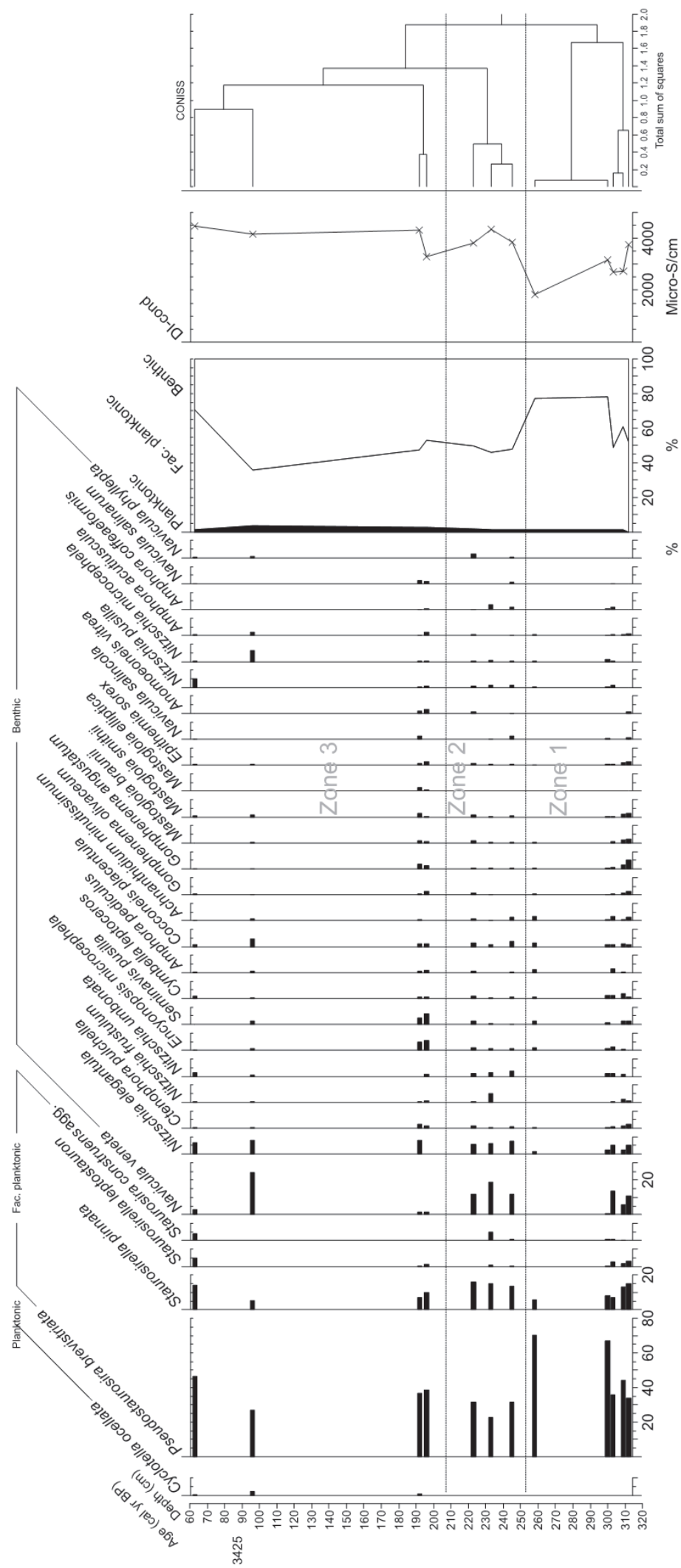




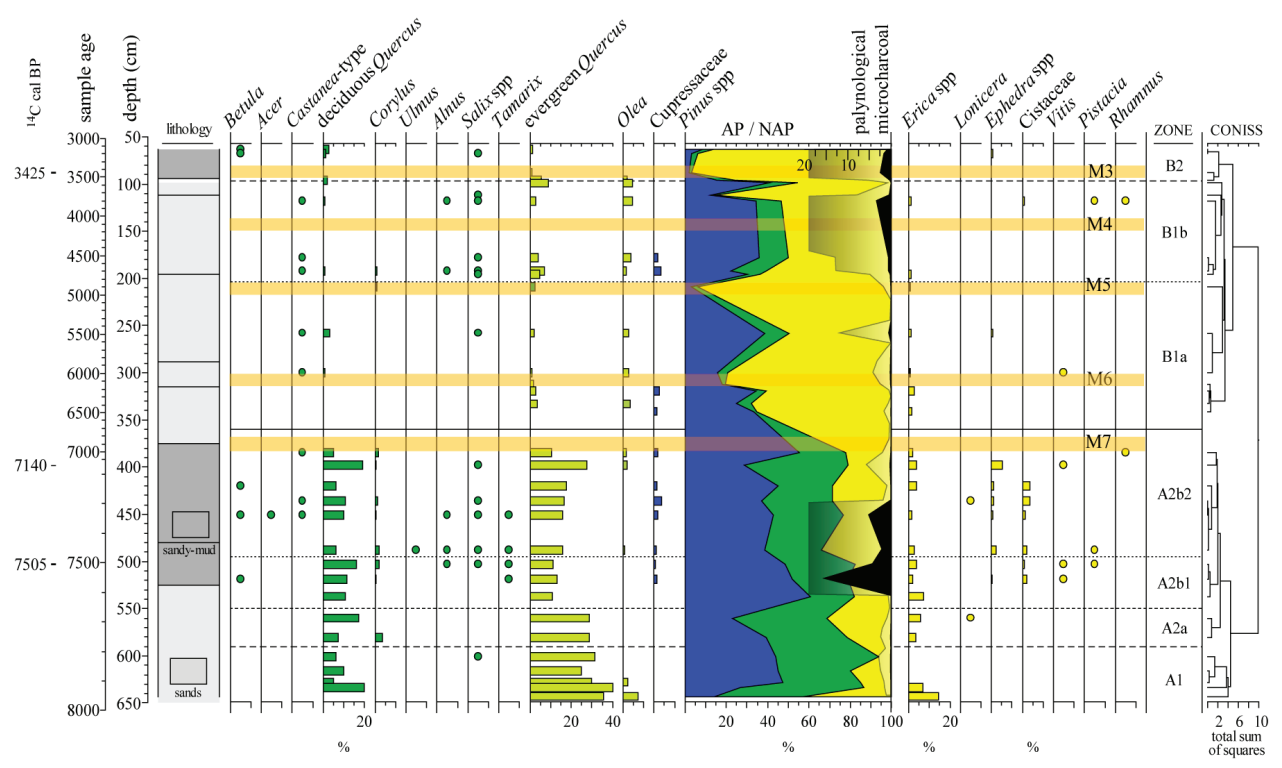

Figure 5. Stratigraphic diagram of pollen percentages (trees and shrubs) and palynological microcharcoal in Lake Albufera core Palmar. The black microcharcoal palynological curve corresponds to the real values (x10000), while its degraded plot corresponds to an exaggeration $\mathrm{x} 20$. The zones defined by constrained cluster analysis are shown on the right. The dots mean less than $1 \%$. The orange bands mark the Minorca events (Frigola et al., 2007). Diagrama estratigráfico de porcentajes polínicos (árboles y arbustos) y microcarbones palinológicos del core Palmar del lago de la Albufera. La curva negra de los microcarbones palinológicos corresponde a los valores reales (x10000), mientras que el gráfico sombreado corresponde a una exageración x20. A la derecha se muestran las zonas establecidas por el análisis de clasificación constreñido. Los puntos indican valores $<1 \%$. Las bandas anaranjadas corresponden a los eventos de Menorca (Frigola et al., 2007).

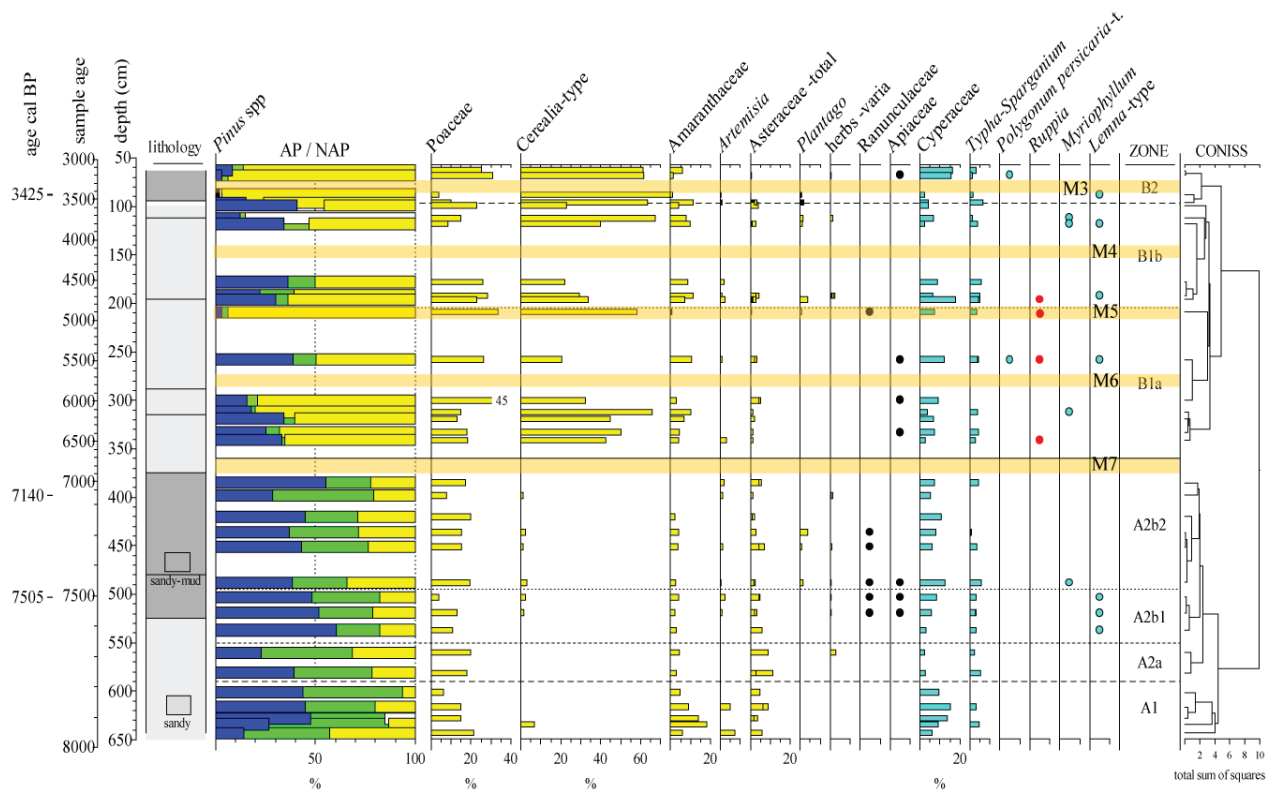

Figure 6. Stratigraphic diagram of pollen percentages of herbs in Lake Albufera core Palmar. The zones defined by constrained cluster analysis are shown on the right. The dots mean less than $1 \%$. The orange bands mark the Minorca events (Frigola et al., 2007). Diagrama estratigráfico de los porcentajes de polen de hierbas en el core Palmar de la laguna de la Albufera. A la derecha se muestran las zonas definidas por un análisis de clasificación constreñido. Los puntos indican valores $<1 \%$. Las bandas anaranjadas corresponden a los eventos de Menorca (Frigola et al., 2007). 
lata, a freshwater taxon of broad tolerances which can withstand low salinity.

\section{Pollen and NPP}

In general, the lower half of the sequence is richer in species and total pollen abundance, allowing greater resolution, whereas the top 350 $\mathrm{cm}$ show lower abundance and even barren samples (Figs. 5-8).

The vegetation of Zone A (643-380 cm, Fig. 5) is dominated by Pinus spp. and Quercus spp., representing an open forest with scrubs, which include mainly Erica spp., Cistaceae, Pistacia sp., with some presence of Ephedra sp. suggesting sand dune habitats (Fig. 5). There is a smooth declining trend of the arboreal pollen towards the top of the sequence, but arboreal pollen abundance is almost always above 70-80 \%. Riparian vegetation is scarcely represented, with presence of Corylus sp., Alnus sp., Ulmus sp., Salix spp. and Tamar$i x$ spp. Probably originating from the surrounding mountain areas, some pollen from Betula sp., Acer sp., Castanea-type and deciduous Quercus sp. is observed also in this zone. At the bottom of the zone $(643-600 \mathrm{~cm}$, zone A1), the high relative abundance of Amaranthaceae (Fig. 6) indicates saline influence in the wetland area; Cyperaceae also occurs, with an approximately negative covariation with Amaranthaceae, suggesting a heterogeneous and variable wetland with variation in soil salinity. From this period on, the Amaranthaceae decline, but are present throughout this zone, while Cyperaceae remains more stable.

Unlike pollen remains, non-pollen palynomorphs (NPPs) are present from the bottom of the sequence (c. 8600 cal. BP at $850 \mathrm{~cm}$ ) (Figs. 7, 8). The base of the sequence $(850-760 \mathrm{~cm}$, subzone A1a) is poor in NPPs, but at the top of this subzone (A1b) the percentages of megaspores (Fig. 7) are remarkably high. The rest of zone A $(700-350 \mathrm{~cm})$ is more diverse (Figs. 7, 8), including mainly algae (Gloeotrichia), fungal (hyphae) and undetermined microzoological remains (type 52).

The upper Zone B $(340-63 \mathrm{~cm})$ shows a large shift of vegetation towards a major reduction in arboreal cover, to less than $50 \%$. Wild grasses (Poaceae) increase up to c. $40 \%$, and Cerealia-type show an exceptional expansion to above $50 \%$. We think that this pollen comes from dune grasses, since we know that some of these species have a size of grain as large as the cultivated cereals (e.g. Joly et al., 2007; Farooq et al., 2015). Besides the major change at c. $340 \mathrm{~cm}$, other notable events of a sharp reduction in arboreal pollen occur at 310, 210 and $90 \mathrm{~cm}$ depth.

Regarding NPPs, Zone B exhibits higher diversity and abundance of fungi and algal remains than Zone A, with a clear increase of Botryococcus spp. (Fig. 7). Polyporisporites also increase in abundance (Fig. 8) but megaspores disappear from this zone. The presence of eggs of parasitic worms (Nematoda) is notable throughout this zone. Charcoal peaks tend to correspond to maximum values of $\mathrm{AP}$, when there is more forest mass available to burn (Burjachs \& Expósito, 2015).

\section{Core Antina}

Marco-Barba et al. (2013b) previously described the chronology, sedimentology and ostracod palaeoassemblages and geochemistry of this sequence, generating the first palaeoenvironmental interpretation of the sequence. Here we add new data on pollen, foraminifera and diatom palaeoassemblages to improve the reconstruction of the recent history of the lake and its surrounding landscape.

\section{Foraminifera}

Only ten species of foraminifera (Fig. 9) were found in this short core (8373 individuals counted), and they were present only at the bottom part (70-50 cm). The species Ammonia tepida (Cushman, 1926), C. excavatum and $H$. germanica dominated, and were the only species present at the top samples (Zone 2) that contained foraminifera. There is a remarkable peak in abundance of Trichohyalus aguayoi (Bermúdez, 1935) at $55 \mathrm{~cm}$, just when most species have disappeared or show low mean abundances.

\section{Diatoms}

Diatoms (Fig. 10) are well preserved throughout, apart from at the start of the sequence, below 60 $\mathrm{cm}$. The sample at $60 \mathrm{~cm}$ only contained 


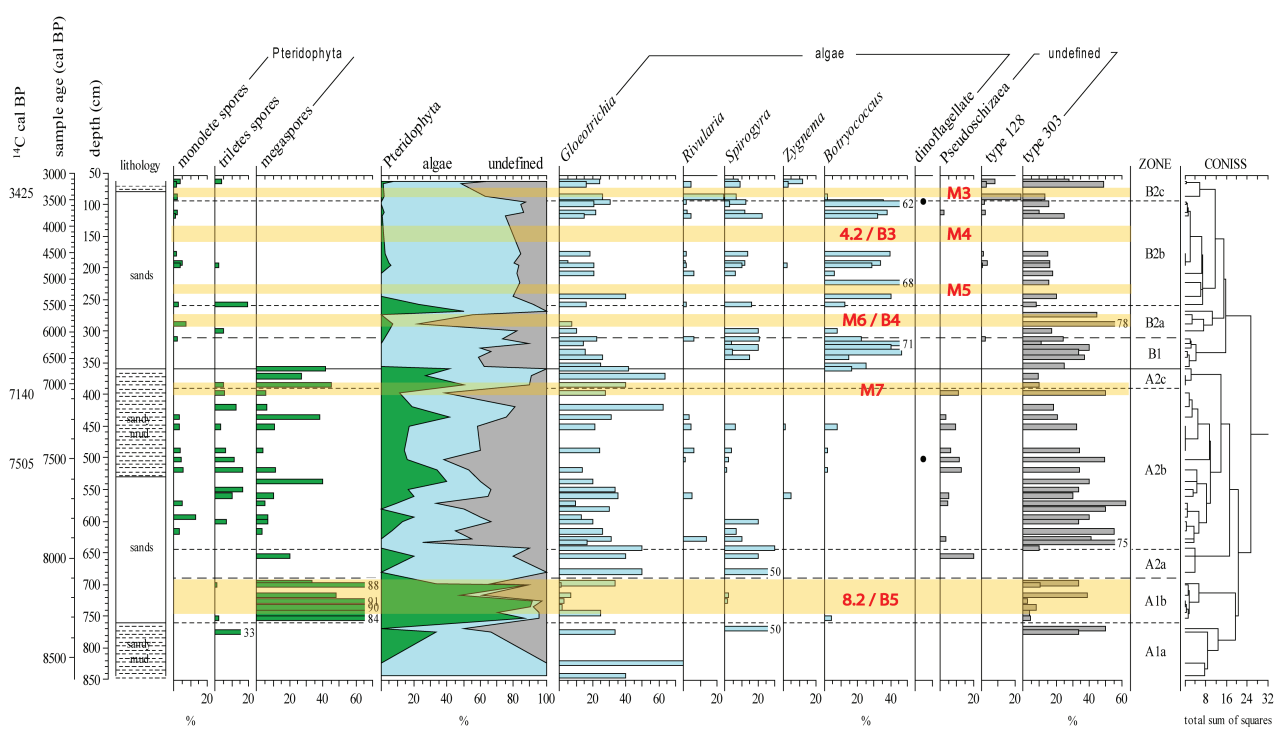

Figure 7. Stratigraphic diagram of Pteridophyta spores, algae and undefined NPPs percentages in Lake Albufera core Palmar. The zones defined by constrained cluster analysis are shown on the right. The dots mean less than $1 \%$. The orange bands mark the Minorca (Frigola et al., 2007) and Bond events (Bond et al., 1997). Diagrama estratigráfico de los porcentajes de esporas de Pteridophyta, de algas y de NPPs no definidos en el core Palmar de la laguna de la Albufera. A la derecha se muestran las zonas definidas por un análisis de clasificación constreñido. Los puntos indican valores $<1 \%$. Las bandas anaranjadas corresponden a los eventos de Menorca (Frigola et al., 2007) y eventos Bond (Bond et al., 1997).

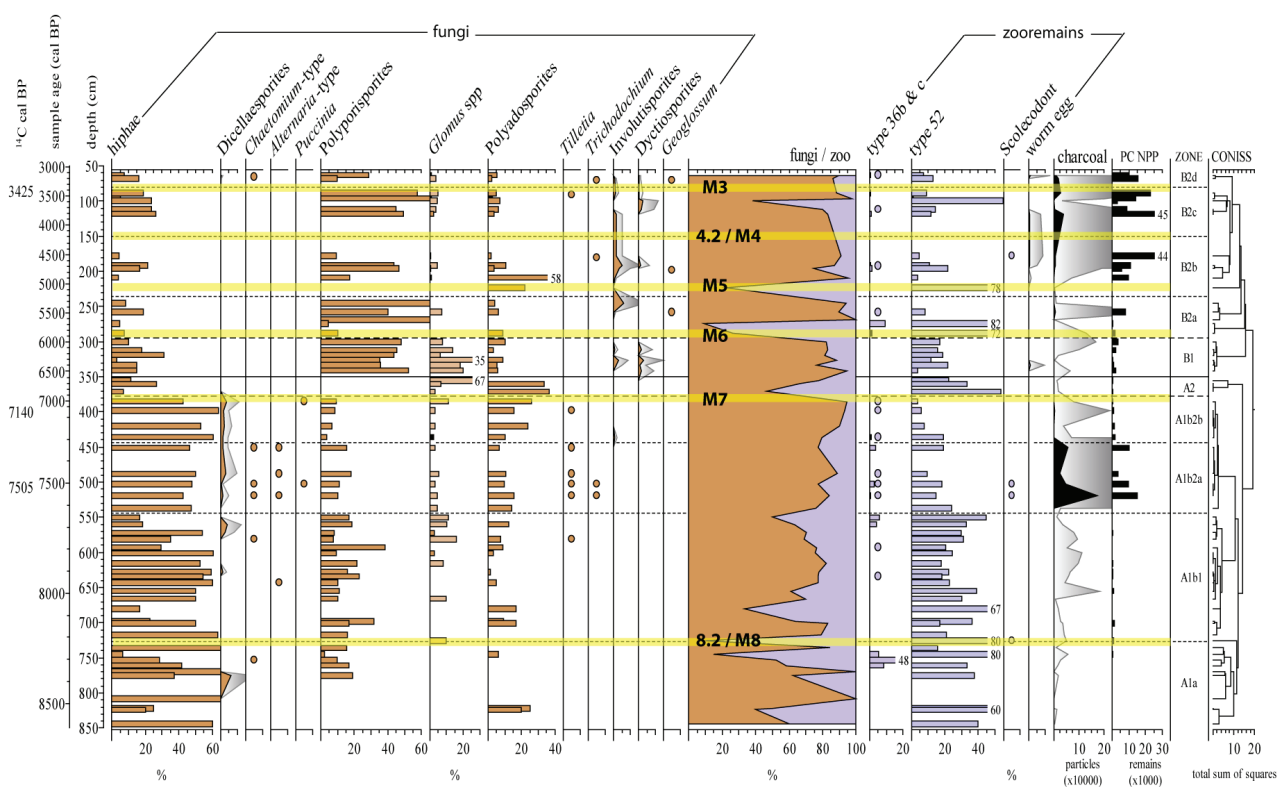

Figure 8. Stratigraphic diagram of fungi, zooremains NPPs percentages, absolute frequencies of palynological charcoal and total concentration of NPPs in Lake Albufera core Palmar. The zones defined by constrained cluster analysis are shown on the right. The dots mean less than $1 \%$. The yellow bands mark the Minorca (Frigola et al., 2007) and Bond events (Bond et al., 1997). The curves exaggeration factor is variable, in order to better visualize its evolution. Diagrama estratigráfico de los porcentajes de hongos, restos de NPPs zoológicos, frecuencias absolutas de carbones palinológicos y concentración total de NPPs en el core Palmar de la laguna de la Albufera. A la derecha se muestran las zonas definidas por un análisis de clasificación constreñido. Los puntos indican valores < $1 \%$. Las bandas amarillas corresponden a los eventos de Menorca (Frigola et al., 2007) y eventos Bond (Bond et al., 1997). El factor de exageración de las curvas es variable, para poder visualizar mejor su evolución. 


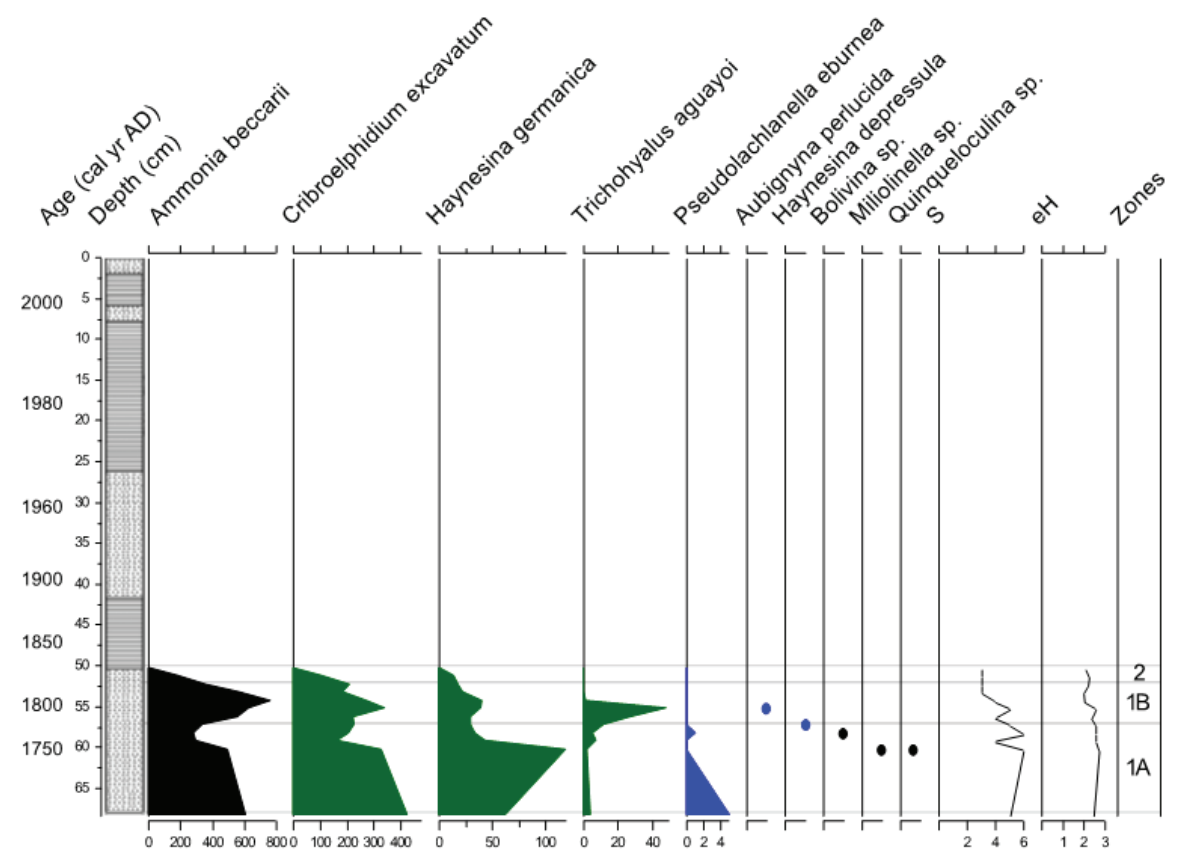

Figure 9. Summary stratigraphic diagram of foraminifera abundances in Lake Albufera core Antina showing taxa present at minimum $>5$ individuals. Green: species tolerant of relatively low salinity in brackish waters (other than Ammonia spp.); blue: those considered less tolerant to low salinity. The diversity of order $0(\mathrm{~S}=$ species richness $)$ and order $1(\mathrm{e} H$, where $\mathrm{H}=\mathrm{Shannon}$ diversity $)$, and zone boundaries defined by constrained cluster analysis are shown on the right. Sediment legend as in figure 2. Gráfico estratigráfico resumen de los foraminiferos del core Antina de la laguna de la Albufera, mostrando las especies con un mínimo de individuos $>5$. Verde: especies tolerantes a salinidades relativamente bajas en aguas salobres (aparte de Ammonia spp.); azul: aquellas poco tolerantes a bajas salinidades. A la derecha se muestran la diversidad de orden 0 ( $S=$ riqueza de especies) y orden 1 ( $e H$, donde $H=$ diversidad de Shannon), así como las zonas definidas mediante análisis constreñido de clasificación. Leyenda de la columna sedimentaria como en la figura 2.

fragments of two species, Campylodiscus clypeus and Diploneis bombus, both of which indicate high conductivity. Above, the sample at $56 \mathrm{~cm}$ is more diverse, preserving some species not present in other dissolved samples: Epithemia argus and Amphora libyca (in addition to $D$. bombus and M. braunii), but again indicates high salinity (Ben Khelifa, 1989; Reed, 1998).

Zone $1(52.5-27.5 \mathrm{~cm})$ is dominated by $P$. brevistriata and a similar range of brackish taxa were present at lower abundance in the lake edge sequence. The dominant benthic taxa, Mastogloia smithii (fresh-brackish) M. braunii (obligate saline) and $M$. elliptica (obligate saline) are typical both of Spanish salt lakes and chloride-dominated estuarine/lagoonal waters. Plankton are represented at $<$ $5 \%$ abundance by Cyclotella meneghiniana, a species common in shallow waters (1-2m depth) of Spanish salt lakes (Reed, 1998). DI-cond tends to fall in the mesosaline range of $>3000 \mu \mathrm{S} / \mathrm{cm}$. A trend towards increased relative abundance of $M$. braunii and $M$. elliptica at the expense of the less salt-tolerant $M$. smithii is matched by peak DI-Cond of c. $7000 \mu \mathrm{S} / \mathrm{cm}$ at $34.5 \mathrm{~cm}$ depth; FP taxa increase towards the upper zone boundary, with an associated reduction in DI-Cond to its minimum for the sequence, in the oligosaline range.

The transition to Zone $2(27.5-0.5 \mathrm{~cm})$ is marked by a sharp increase and subsequent dominance of planktonic $C$. meneghiniana at the expense of FP and the range of benthics present in Zone 1. A range of Nitzschia taxa (N. frustulum, $N$. linearis and $N$. hungarica appear for the first time. C. meneghiniana is again a taxon of very broad tolerance. It is a common diatom of saline waters, but also of hypereutrophic or generally polluted fresh water (Mills \& Ryves, 2012). Its high conductivity optimum drives the mainte- 

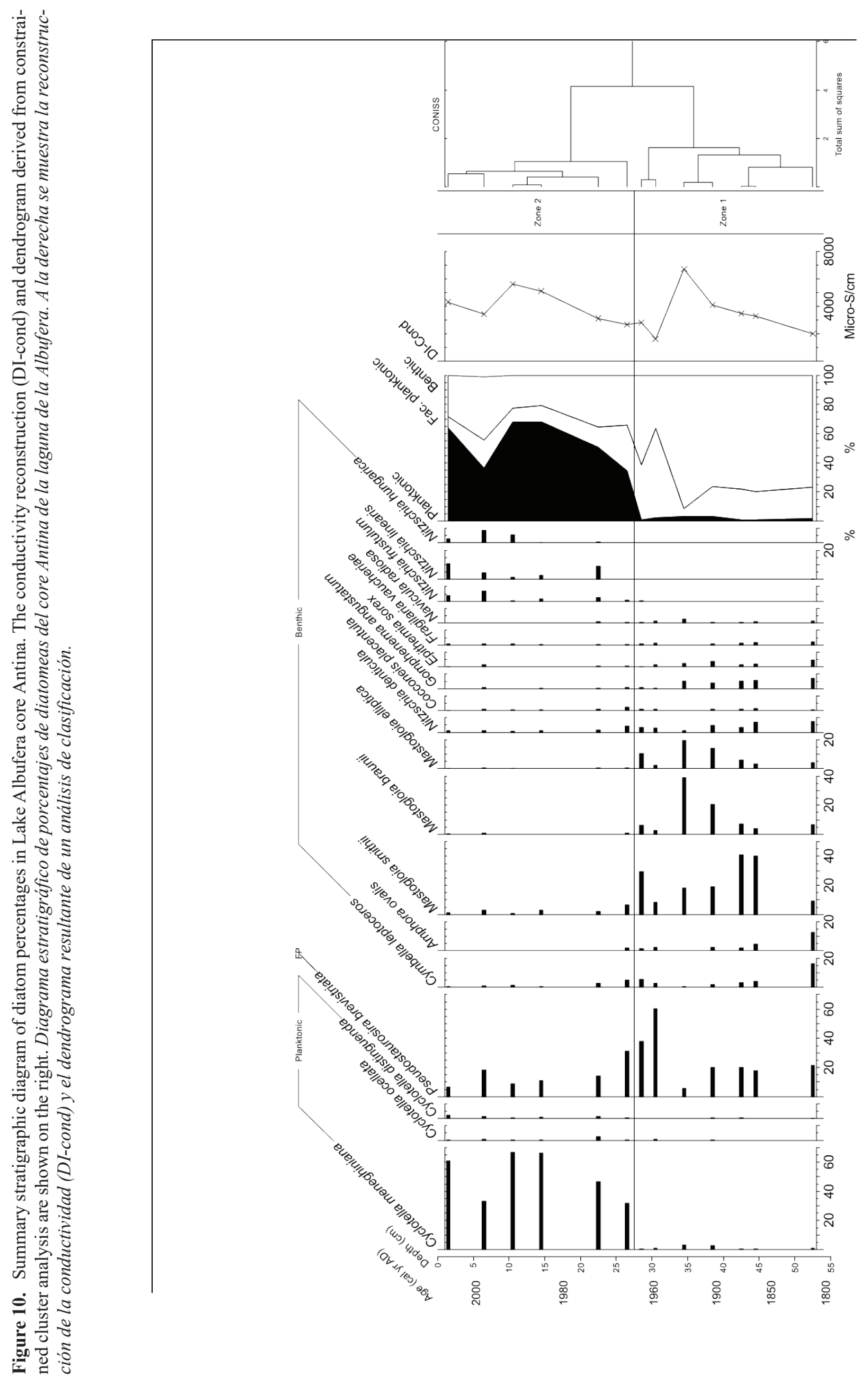
nance of DI-Cond at c. $4000 \mu \mathrm{S} / \mathrm{cm}$, but this may be overestimated. The increase in Nitzschia taxa at the expense of Mastogloia points to a marked reduction in salinity.

\section{Pollen}

Subzone A1a: $61-55 \mathrm{~cm}$

The percentage of arboreal pollen (AP) is relatively high (c. 40-80\%) at the base of the sequence, dominated by Pinus (pines), Quercus evergreen and $Q$. deciduous (Holm oak, oaks), Olea-Phillyrea (olive tree, wild olive, green olive tree) and Cupressaceae (Fig. 11). The shrub component is most represented by heathers (Erica). The relatively high abundance of Amaranthaceae and Artemisia, the scarcity of freshwater algae and low values of hygro-hydrophytes (Cyperaceae, Lemna-type, Typha-Sparganium, Myriophyllum), all point to the influence of salinity (Fig. 12).

\section{Subzone A1b: 55-46 cm}

Here, there is a general reduction in AP despite increasing tree diversity. While the bushes remain stable, wild grasses (Poaceae) and Cerealia-type pollen (up to $5.5 \%$ ) increase. The highest abundances of Faboideae and Asteraceae are noted in this subzone and the aquatic plant Myriophyllum onset its presence, although at low abundance. A small peak in Pseudoschizaea abundance, which is considered an NPP associated to erosion (Pantaleón-Cano et al., 1996), is also noticeable (Fig. 13). This may indicate enhanced sediment input, maybe favoured by forest fires, as also suggested by a peak in microcharcoal at that time (Fig. 13).

\section{Subzone A2: $46-38 \mathrm{~cm}$}

Forest vegetation (AP) recovers up to levels similar to those of subzone A1 (43-60\%). Pollen salinity indicators (Amaranthaceae) decrease even more now, and pollen from riparian trees (Corylus, Alnus), which have appeared in the previous subzone, now increase, as well as the relative abundance of algal remains and the aquatic plant Myriophyllum, suggesting fresher conditions of the water body. A peak of Juglans (walnut tree) and the presence of Morus (used to feed silk moth caterpillars) indicate changes in land use with more importance of the trees cultivation.

\section{Subzone B1: $38-30 \mathrm{~cm}$}

This subzone marks the onset of a new vegetation regime (Figs. 11 and 12). Initially, the climactic vegetation (oaks) retreats in favour of conifers (pines and Cupressaceae). By the end of this subzone, arboreal vegetation in general declines (particularly for Olea sp. and Quercus sp.), with a concomitant increase in grasses (Poaceae, up to $30 \%$, Fig. 12). The marked decrease in the aquatic plant Myriophyllum, and increase in fungi (type Polyadosporites, zone A2 in Fig. 13) suggest higher turbidity, possibly associated with eutrophication. This process may be also related to the rise in Cosmarium algal remains (zone A2 in Fig. 13). Most probably, the littoral areas of the lake suffered temporary variations in inundation through time, favouring the increase in Cyperaceae and grasses (Fig. 12).

Subzone B2a: 30-17 cm

Pine forests increase at this zone, although there is a reduction at the top of the subzone, related to fires, as indicated by microcharcoal increase (zone B1 in Fig. 13). Riparian areas seem now dominated mostly by bulrush (cf. Typha) rather than by common reed (cf. Phragmites included in Poaceae). The transition between the previous zone and this one is indicated by the input of detritic sediments (Glomus and, later, the type Pseudoschizaea), at the same time that there is an increase in microalgae Spirogyra, Botryococcus and Pediastrum, as a response to a relative reduction of Cosmarium. There is evidence throughout for cultivation (Cerealia), with the presence of mulberry trees (Morus sp.) At about $25 \mathrm{~cm}$ deep, the first presence of Myrtaceae occurs, probably indicating an increase in Eucalyptus plantations or extension of Myrtus (common myrtle).

Subzone B2b: 17-6 cm

This subzone is very similar to the previous one, but with evidence for a slight recovery of the 


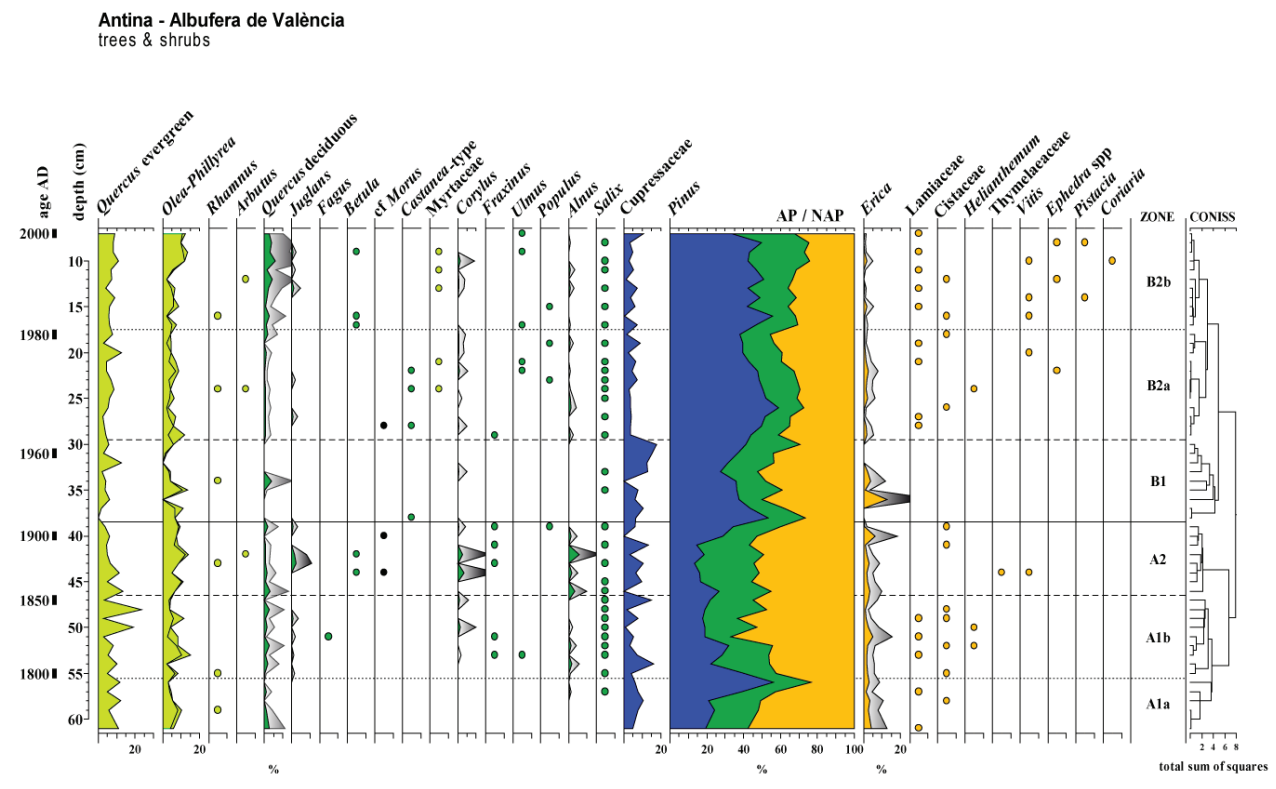

Figure 11. Stratigraphic diagram of pollen percentages in Lake Albufera core Antina. The zones defined by constrained cluster analysis are shown on the right. The dots mean less than $1 \%$. The curve exaggeration factors are variable, in order to better visualize their evolution. Diagrama estratigráfico de los porcentajes de polen en el core Antina de la laguna de la Albufera. A la derecha se muestran las zonas definidas por un análisis de clasificación constreñido. Los puntos indican valores $<1 \%$. El factor de exageración de las curvas es variable, para poder visualizar mejor su evolución.

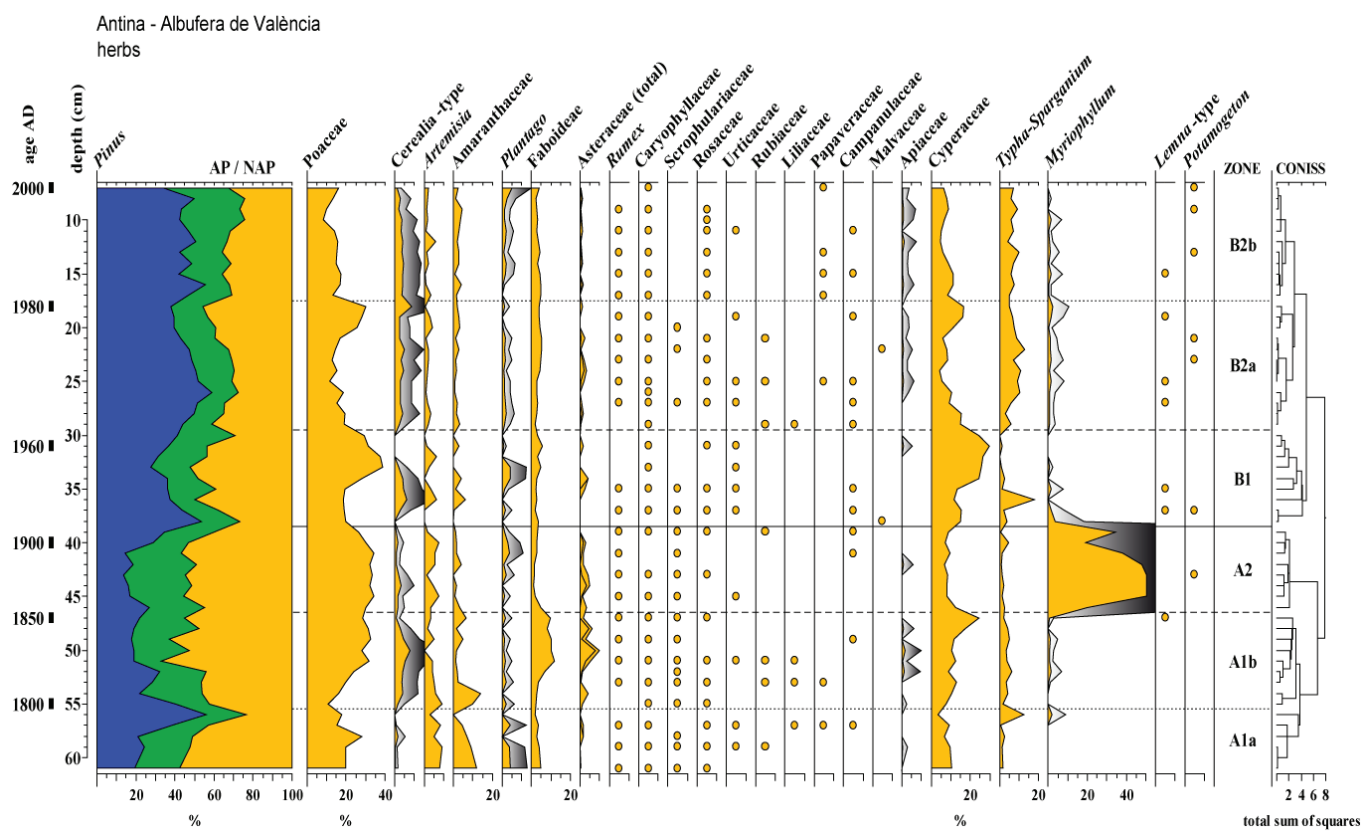

Figure 12. Stratigraphic diagram of pollen percentages of herbs in Lake Albufera core Antina. The zones defined by constrained cluster analysis are shown on the right. The dots mean less than $1 \%$. The curves exaggeration factor is variable, in order to better visualize their evolution. Diagrama estratigráfico de los porcentajes de polen de hierbas en el core Antina de la laguna de la Albufera. A la derecha se muestran las zonas definidas por un análisis de clasificación constreñido. Los puntos indican valores $<1 \%$. El factor de exageración de las curvas es variable, para poder visualizar mejor su evolución. 


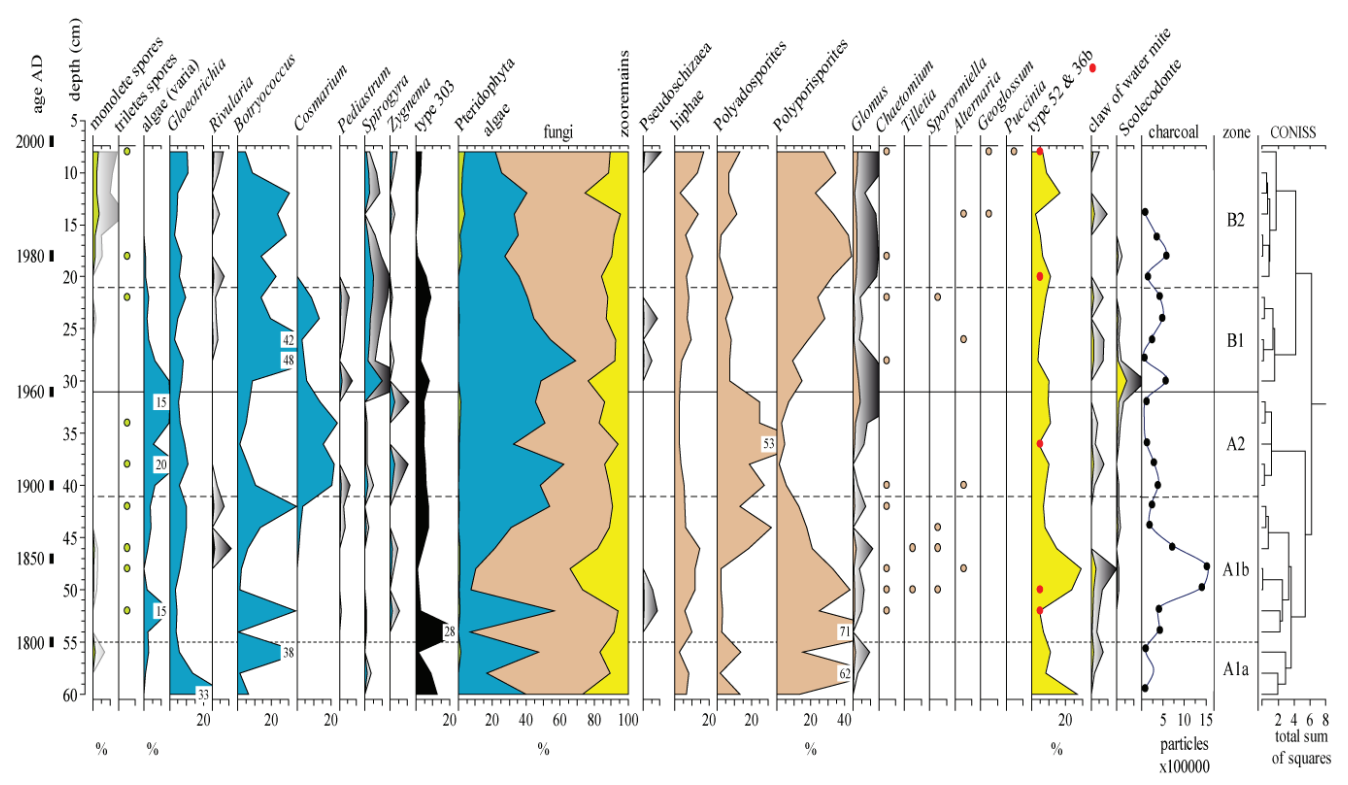

Figure 13. Stratigraphic diagram of Pteridophyta, algae, fungi, zooremain NPPs percentages and absolute frequencies of palynological charcoal in Lake Albufera core Antina. The zones defined by constrained cluster analysis are shown on the right. The dots mean less than $1 \%$. The curves exaggeration factor is variable, in order to better visualize their evolution. Diagrama estratigráfico de los porcentajes de Pteridophyta, algas, restos NPPs zoológicos y frecuencias absolutas de carbones palinológicos en el core Antina de la laguna de la Albufera. A la derecha se muestran las zonas definidas por un análisis de clasificación constreñido. Los puntos indican valores $<1 \%$. El factor de exageración de las curvas es variable, para poder visualizar mejor su evolución.

forest, along with the constant presence of Myrtaceae and cultivated cereals. No Morus remains are observed anymore. Freshwater taxa (Cyperaceae, Typha/Sparganium, cf. Phragmites, Pteridophyta monolete spores) continue to dominate over saline indicators (Amaranthaceae, Artemisia).

\section{Core Centre}

A brief summary of the top part of this core and its interpretation was previously given by MarcoBarba et al. (2012a). In this paper, we provide a detailed description of the stratigraphic sequence (Fig. S1, available at http://www.limnetica.net/en/ limnetica), including the chronology (Fig. 14), information on chemical composition and a detailed XRF analysis of the sediments (Figs. 15, 16, S2 (available at http://www.limnetica.net/en/ limnetica)), so as on foraminifera remains (Figs. S3 (available at http://www.limnetica.net/en/ limnetica),17) and ostracod palaeoecology and geochemistry (Figs. S4 (available at http://www. limnetica.net/en/limnetica), 18, 19).

\section{Chronological framework}

For the top of the core a $210 \mathrm{~Pb}$-based cf:cs chronology was constructed from the near-exponential section of the twin core (14-35 cm), which yielded dates that match the $137 \mathrm{Cs}$ record fairly closely, giving a sedimentation rate of $6 \mathrm{~mm} / \mathrm{yr}$ for the twin core Centre (Fig. 14), after lithological matching. This is supported by the very high magnetic susceptibility peak at the top of Core Centre (30 cm depth) that coincides with an important flood event in 1957, which markedly affected Albufera lake (Fig. S1; Carmona \& Ruiz, 2000). Thus, the chronology presented here is arranged to fit the radiocaesium results, with the flood event as a tie marker. The year $1850 \mathrm{AD}$ at the base of $210 \mathrm{~Pb}$ profile could be placed at $75 \mathrm{~cm}$ in core Centre, which fits with a change in the $\mathrm{Sr} / \mathrm{Ca}$ content (Figs. 14,16) a shift of facies (top of Cerastoderma shells, Fig. S1) and coincides with a major expansion of the irrigation system at the beginning of the 19th century (Sanchis Ibor, 2001). A sedimentation rate of $4.2 \mathrm{~mm} / \mathrm{yr}$ is 

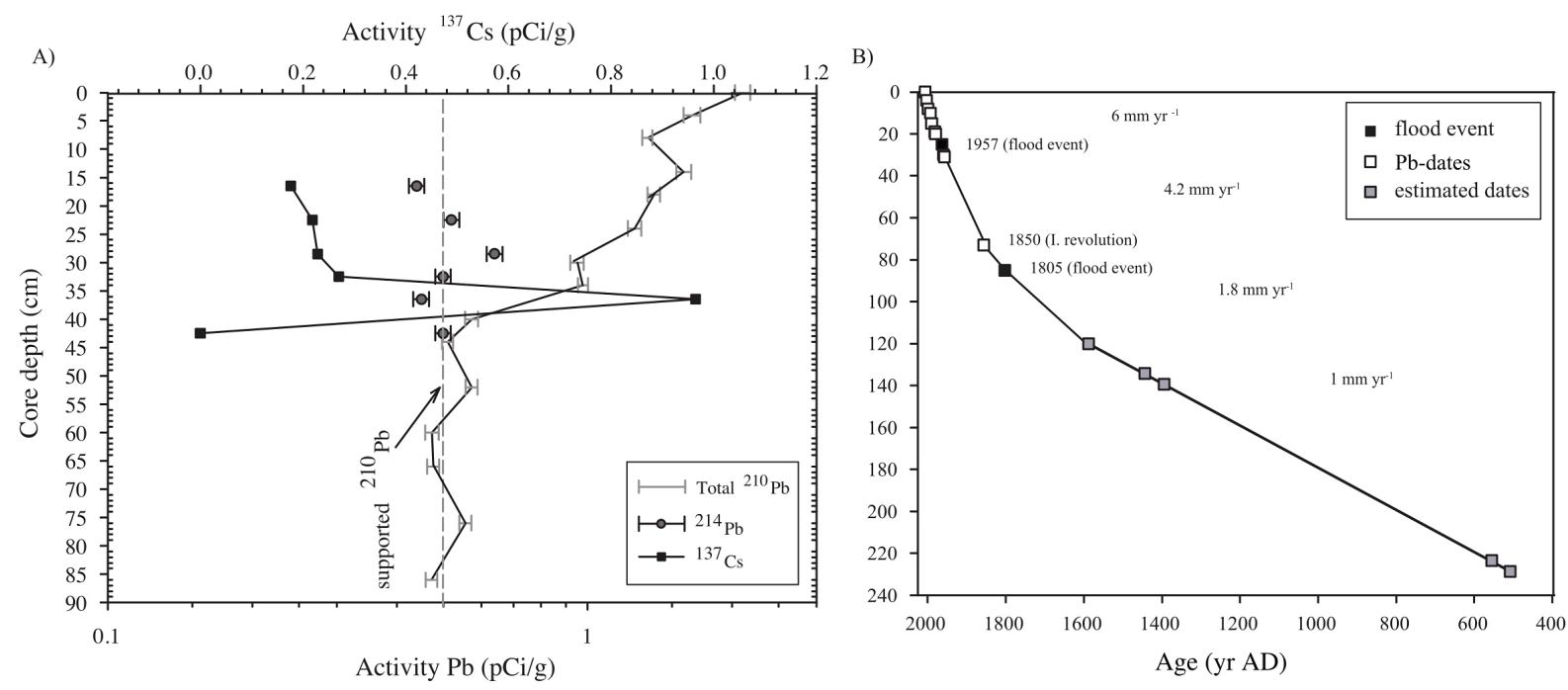

Figure 14. A) Radionuclide activities of ${ }^{210} \mathrm{~Pb}$ (gray straight line), ${ }^{214} \mathrm{~Pb}$ (gray circles) and ${ }^{137} \mathrm{Cs}$ (black squares) from Core Centre. Note that supported activity is also placed. B) Chronological model and sedimentation rates estimated from ${ }^{14} \mathrm{C}$ dates and historical data (see text). A) Actividades ( $\mathrm{pCi} / \mathrm{g}$ ) de los radioisótopos $210 \mathrm{~Pb}$ (línea gris), $214 \mathrm{~Pb}$ (puntos grises) y $137 \mathrm{Cs}$ (cuadrados negros) del Core Centre. También se indica la actividad basal. B) Modelo cronológico y tasas de sedimentación estimadas a partir de dataciones ${ }^{14} \mathrm{C}$ y datos históricos (ver texto).

estimated for the period 1850-1957 (Fig. 14). Just below that depth there are peaks in magnetic susceptibility and detrital elements (Figs. 15,16) that could be related to the very frequent acute storm episodes occurring in the wet years at the start of the XIX century (e.g. a very intense one in 1805; Carmona \& Ruiz, 2000) involving again the rivers and water courses surrounding Albufera lake. So, we placed in our chronological model the year 1805 as corresponding to the magnetic susceptibility peak at $85 \mathrm{~cm}$ depth (Fig. 15) The peak could be additionally reinforced by the transportation of large volumes of sediment to transform the shallow peripheral parts of Albufera into rice paddies (increasing $\mathrm{Ti} / \mathrm{K}$ ) that took place mainly from the end of the $18^{\text {th }}$ to the beginning of the 19th century. This chronology fits also with $\mathrm{XRF}$ results (Fig. 16); the $\mathrm{Pb}$ accumulation would increase after the start of the Industrial Revolution (starting between 1800-1850 AD in Europe and by the end of this period in Valencia, Renberg et al., 2001; Bindler et al., 2008), and $\mathrm{Cu}$ would increase with its use in the switch of rice cultivation from transplanting to direct seeding in the 1960's (Zaragoza Pérez, 1982).
The lower part of the chronological model (Fig. 14) is based additionally on radiocarbon dates (Table 1), which probably had a strong reservoir effect, but used to calculate sediment accumulation rate (SAR), plus historical data and XRF geochemistry. The reservoir effect can be very high and very variable (Sabatier et al., 2010; 2012), especially when there is influence of freshwater rich in (bi-)carbonates, so that measured ${ }^{14} \mathrm{C}$ dates in such context can be up to $>2000 \mathrm{yr}$ older than expected, and strongly depends on alkalinity (Coularis et al., 2016). This effect can apply not only to shelled invertebrates, but also to aquatic plants with aerial parts (Philippsen, 2013; Philippsen \& Heinemeier, 2013). Therefore, shell and pollen ${ }^{14} \mathrm{C}$ dates from lake Albufera sediments could be much older than the finally calibrated dates, taking into account the strong influence of freshwater input throughout its history (e.g. Marco-Barba et al., 2013a,b), with variable and high alkalinity in recent times (Soria et al., 1987). Anyway, the lower part of the core has a very stable $\mathrm{Cl}$ content, indicating insignificant anthropogenic changes in the hydrology of the lagoon, thus, a relative stability in the reservoir 
effect can be assumed, allowing average sediment accumulation rate (SAR) to be estimated from radiocarbon measurements of the same type of material at different depths. Average rates calculated independently from pollen and shell data for the lower part of the core showed similar values of around $1 \mathrm{~mm} / \mathrm{yr}\left(\mathrm{SAR}_{\text {pollen: }}\right.$ 0.94-0.97 $\mathrm{mm} / \mathrm{yr}$ and $\mathrm{SAR}_{\text {shells: }}$ 1.05-1.23 $\mathrm{mm} / \mathrm{yr}$ ). This was taken as the average SAR from the core base to $120 \mathrm{~cm}$, after which a sharp $\mathrm{Cl}$ decrease occurs (Fig. 16). This shift in the Cl values is thought to be related to the construction of a gate in the outlet of the lagoon to the sea for fishing management in 1607, and consequently we assigned the date of $1600 \mathrm{yr}$ AD to a core depth of $120 \mathrm{~cm}$. This hydrological control, together with an increased drainage to this lagoon outlet from irrigation ditches, limited water interchange with the sea and reduced the salinity of the lagoon according to historical documents compiled by Sanchis Ibor (2001). Assuming that the depth of $120 \mathrm{~cm}$ corresponds to the first quarter of the 17 th century, a SAR of $1.8 \mathrm{~mm} / \mathrm{yr}$ could be assigned to the $75-120 \mathrm{~cm}$ interval (Fig. 14). These age estimates suggest that the results of shell analysis incorporate a reservoir effect $(\mathrm{R}(\mathrm{t}))$ much higher than the expected marine reservoir age in the Mediterranean Sea (about 400 years; Siani et al., 2000), in accordance with observations in nearby coastal systems by Sabatier et al. $(2010 ; 2012)$. This estimated effect was between 1450 and 2349 yr (Table 1) for our calibrated ${ }^{14} \mathrm{C}$ dates (excluding a much older outlier at $233 \mathrm{~cm}$ core depth), higher for pollen than for shell material. Due to the large uncertainty of the reservoir corrections and sedimentation of older materials, the radiocarbon results have therefore only been used as relative measurements, and those of the uppermost stratum (above $120 \mathrm{~cm}$ core depth) have been excluded, because deposition occurred in different and more variable hydrological conditions. Still, we estimated also a reservoir effect of 669-817 yr for the two top calibrated dates.

\section{Lithological facies descriptions}

Clay and silt sediments with shell fragments mostly filled the lagoon alternating with layers of fine sandy material. Two sedimentary units (Unit
1 and 2) and five lithological facies (A, B, C, D, and $\mathrm{E}$; described below) were recognised from Core Centre, based on visual inspection (Fig. S1). Magnetic susceptibility (MS), LOI, percentage of carbonates and X-ray fluorescence (XRF) profiles were used to better define these facies. Unit 1 was identified from the base of the core at $235 \mathrm{~cm}$ to $81 \mathrm{~cm}$ depth and unit 2 from $81 \mathrm{~cm}$ to the core top.

Levels making up facies A are characterized by different thickness varying between $3 \mathrm{~cm}$ and $18.5 \mathrm{~cm}$ (A1 to A6), all of them belonging to unit 1. This facies is formed by gray sandy silt sediments, carbonate grains and plant fragments. Bioclasts of gastropods and bivalves, mainly Cerastoderma glaucum (Poiret, 1789) valves, and also foraminifera could be found.

Facies B is formed by homogeneous fine silt sediments with gray coloration (Fig. S1). Seven levels were described at this lithofacies (B1-B7) with different thickness (between $4 \mathrm{~cm}$ and 30 $\mathrm{cm}$ ), all located at unit 1 . They are characterized by very low sand content, plant fibre remains of variable length and microscopic carbon particles. Bioclasts of molluscs and articulated valves were usually absent or scarce (facies B2-B7).

Facies $\mathrm{C}$ is formed by homogeneous ochre fine silt sediments highly enriched in plant remains. Five levels were identified (C1-C5) with different thickness and present in both units 1 and 2, usually made up of narrow layers (range 3 - 36 $\mathrm{cm}$ ). Facies $\mathrm{C} 1$ and $\mathrm{C} 3$ were composed of plant remains of different lengths, bioclasts of molluscs and articulated valves of Cerastoderma glaucum. Facies A5/C2 showed the typical sediment composition of facies $\mathrm{C}$ although highly enriched in sand. Facies $\mathrm{C} 4$ and $\mathrm{C} 5$ are composed of soft pink (C4) and orange (C5) mud sediments with carbonate grains (C4) and are confined to unit 2.

Facies D is mostly composed of homogeneous silt, with two narrow layers with some fine sand at the top. Plant and mollusc remains are very scarce.

Facies $\mathrm{E}$ is formed by heterogeneous dark grey silt sediments, without plant and mollusc remains. Five levels were identified as lithofacies E1 to E5, always consisting of very thin layers (range $0.5-3 \mathrm{~cm}$ ). The majority of these levels coincide with MS increases (Fig. 15), mainly at E4 and E5 with the highest MS peaks. Based on 
the high content of detritic elements such as titanium, potassium and aluminum, this material was probably reworked and transported into the lake due to flood events.
XRF results

The high-resolution records of the most significant geochemical elements obtained by the XRF
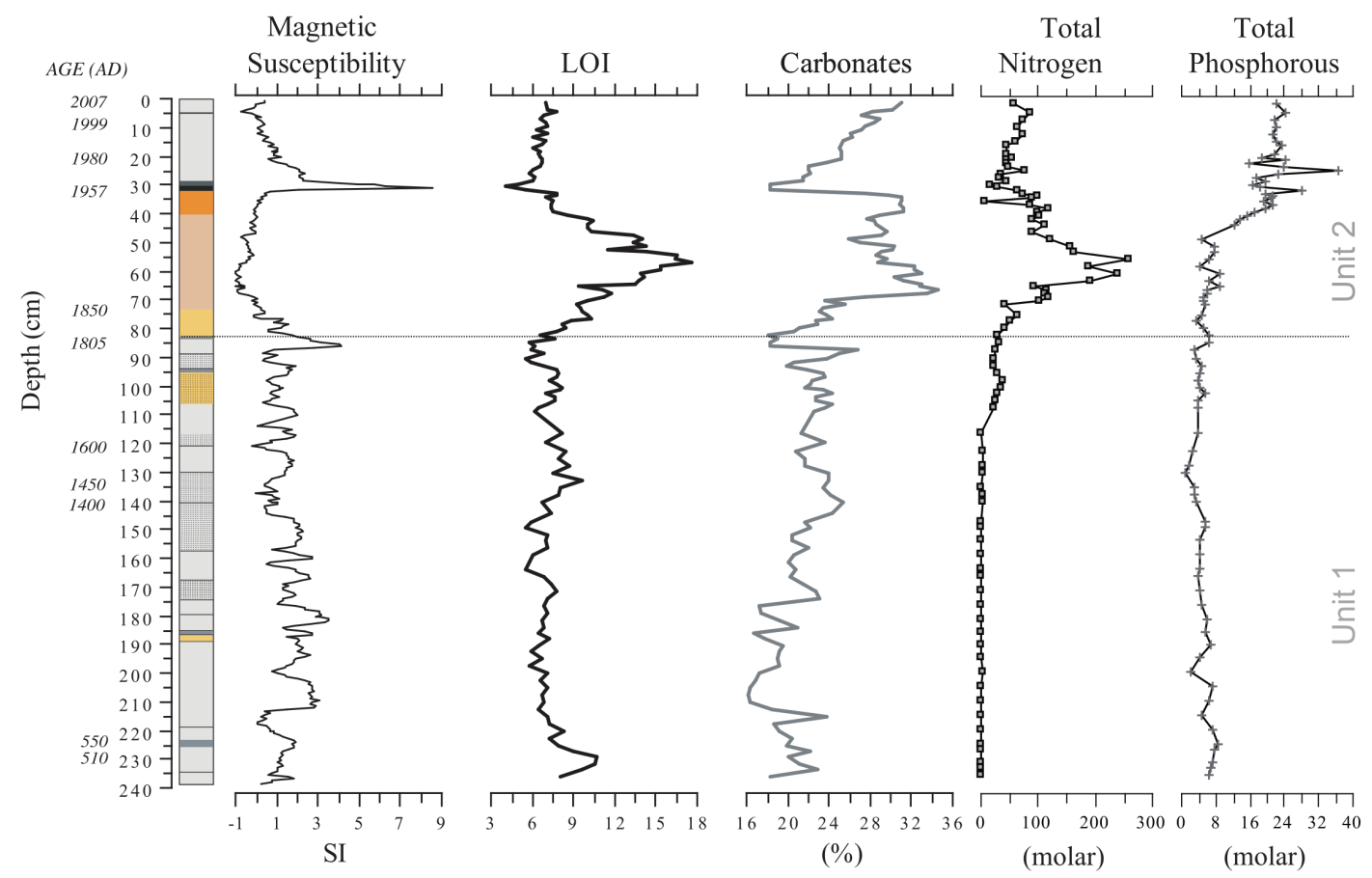

Figure 15. Magnetic susceptibility (MS), loss on ignition (LOI), \% carbonates, total nitrogen (TN) and total phosphorus (TP) of Core Centre. Susceptibilidad magnética (MS), pérdida por ignición (LOI), \% de carbonatos, nitrógeno total (TN) y fósforo total (TP) del core Centre.

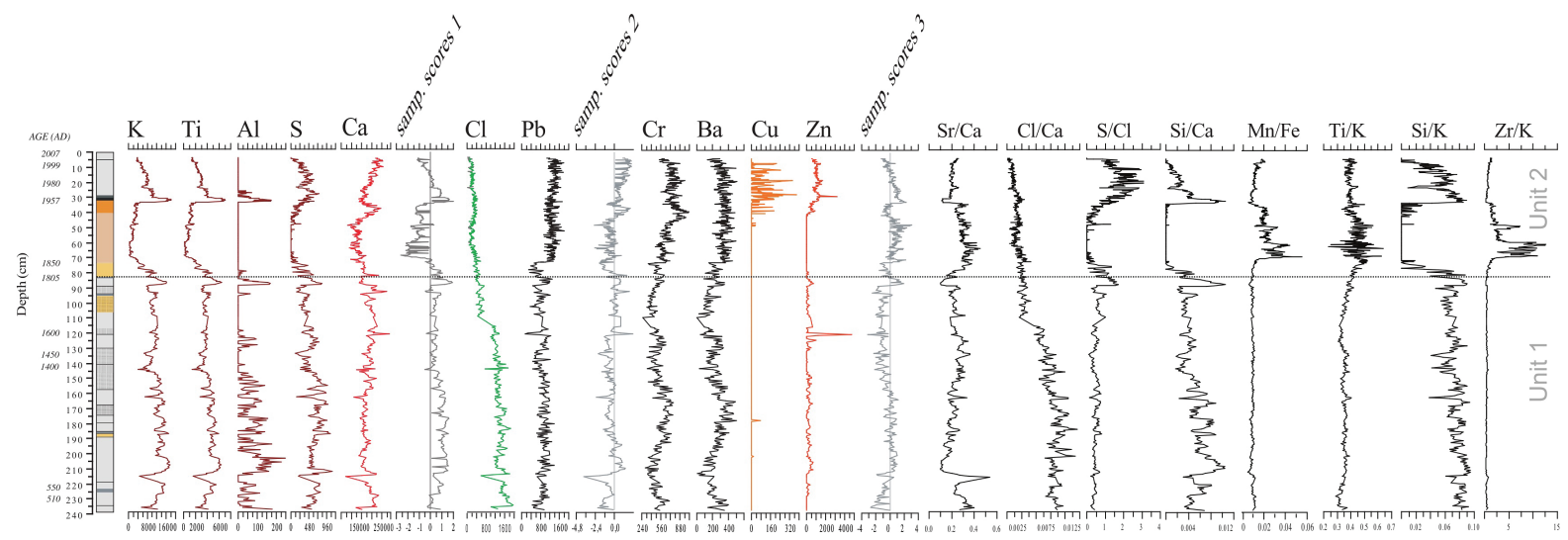

Figure 16. Stratigraphic diagram of geochemical XRF fluorescence data from Core Centre. The samples scores 1, 2 and 3 from a PCA are also plotted. See Figure S2. Diagrama estratigráfico de los datos geoquímicos de fluorescencia XRF del core Centre. Se muestran además los valores de las muestras para los factores 1, 2 y 3 de un análisis de componentes principales (PCA). Ver Figura S2. 
analysis are plotted in figure 16. Two kinds of profiles are easily seen reflecting the distinct varying proportion of authigenic versus detrital elements with core depth. The variation of $\mathrm{Ca}$ and $\mathrm{Sr}$ can be mainly related to shell abundance (molluscs, ostracods, foraminifera, Sabatier et al., 2010,2012 ) (sedimentary unit 1 ) or to endogenic carbonate precipitation (unit 2). In the sedimentary unit 2 carbonate shells were very scarce and the increase in $\mathrm{Ca}$ and carbonates should be predominantly associated to precipitation of calcium carbonate due to high photosynthetic rates, first mediated by the development of aquatic macrophytes and, since the end of the 1960's $(20-25 \mathrm{~cm})$, by phytoplankton production, although some influence of clastic carbonate input from the watershed cannot be disregarded.

On the other hand, detrital elements, Ti, K altogether with quartz ( $\mathrm{Si}$ ) clay elements $(\mathrm{Al}, \mathrm{Fe}$, $\mathrm{Rb}$ ), suggest allochthonous input materials (Cohen, 2003; López-Buendía et al., 1999). Particularly, $\mathrm{Ti}$ and $\mathrm{K}$ are considered detrital elements from continental sources (Cohen, 2003; López-Buendía et al., 1999), and are highly positively correlated with MS $(p<0.01)$ along the core, and negatively correlated with LOI and the proportion of carbonates $(p<0.01)$, suggesting that these elements were mostly deposited into the lake by inlets and particularly flood events. In addition, we find heavy elements mostly derived from human activities to increase their concentrations to the upper parts of the core; $\mathrm{Cr}$ and $\mathrm{Pb}$ increasing since about $80 \mathrm{~cm}$ depth and $\mathrm{Cu}$ and $\mathrm{Zn}$ later at the top of the sequence. $\mathrm{Cl}$ indicates the higher bottom salinity with an important shift at about $120 \mathrm{~cm}$ and progressively decreasing to the top of the sequence. Although this reduction in $\mathrm{Cl}$ content might also be related to a reduction in sediment grain size (and water accumulated therein), the salinity change is also supported by a reduction in foraminifera diversity and stenohaline marine ostracod relative abundance (see below).

PCA results (Fig. S2, available at http://www. limnetica.net/en/limnetica) confirm the opposite distribution between elements with detrital origin and characteristic of high erosive periods (or clastic input), and elements more characteristic of authigenic stable periods (or carbonate input). This is indicated by axis 1 , which accounts for most of the variance of the data (90\%). Detrital elements cluster with high positive scores, Ti, Fe and $\mathrm{K}$ showing the higher scores followed closely by $\mathrm{Co}, \mathrm{Rb}, \mathrm{Si}$, and to a lesser extent by $\mathrm{S}$ and $\mathrm{Al}$. High negative scores are displayed by $\mathrm{Ca}$ and $\mathrm{Sr}$, followed by the compact group of $\mathrm{Ni}, \mathrm{Cr}, \mathrm{Pb}$, and by $\mathrm{Zr}$ and $\mathrm{Ba}$. Although explaining a low proportion of the total variance, the separation along axis 2 between $\mathrm{Zn}$ and $\mathrm{Cu}$ (positive scores) and $\mathrm{Cl}$ and As (negative scores) reflects salinity variation. The former two elements (usually related to chemical industrial activities, but also agricultural practices in the case of $\mathrm{Cu}$ ) are more important at the very top of the core. Due to the proximity of the lake to the sea, $\mathrm{Cl}$ and As (a good pyrite indicator) variation probably indicate variation in marine influence. $\mathrm{Cl}$ was negatively correlated with the proportion of carbonates $(p<0.01)$, suggesting that sea water played an important role in the geochemical composition of the lagoonal sediments in the lower half of the core.

The ratios between elements (Fig. 16) clearly indicate shifting paleoenvironmental conditions; $\mathrm{Cl} / \mathrm{Ca}$ show the salinity change, while $\mathrm{Sr} / \mathrm{Ca}$ indicates a zone of change in the type of carbonates in the lower part of unit 2 at the onset of desalinization, when macrophytes were abundant and diminished afterwards. Contrarily, the $\mathrm{S} / \mathrm{Cl}$ ratio indicates a reverse pattern for $\mathrm{S}$, with peaks that may indicate sulphide-rich matter originated in anoxic conditions (Zwolsman et al., 1993 ) at the top and bottom of sedimentary unit 2 , but lower values at the more stable redox conditions of macrophyte development prior to eutrophication. Also, $\mathrm{Si}$ as well as clay elements show a very scarce concentration in this zone, altogether with detrital elements but the reduction of the later is much less marked. Thus, the ratio $\mathrm{Ti} / \mathrm{K}$ shows a slight increase also in this zone. The $\mathrm{Mn} / \mathrm{Fe}$ ratio marks also clearly this zone, with $\mathrm{Mn}$ higher values in the stable redox (macrophyte-dominated) zone, probably due to the faster oxidation of $\mathrm{Fe}$ (Zwolsman et al., 1993).

\section{Foraminifera}

Selected common foraminifera taxa in Core Centre are shown in figure S3. This core was (almost) barren of foraminifera in the upper 70 


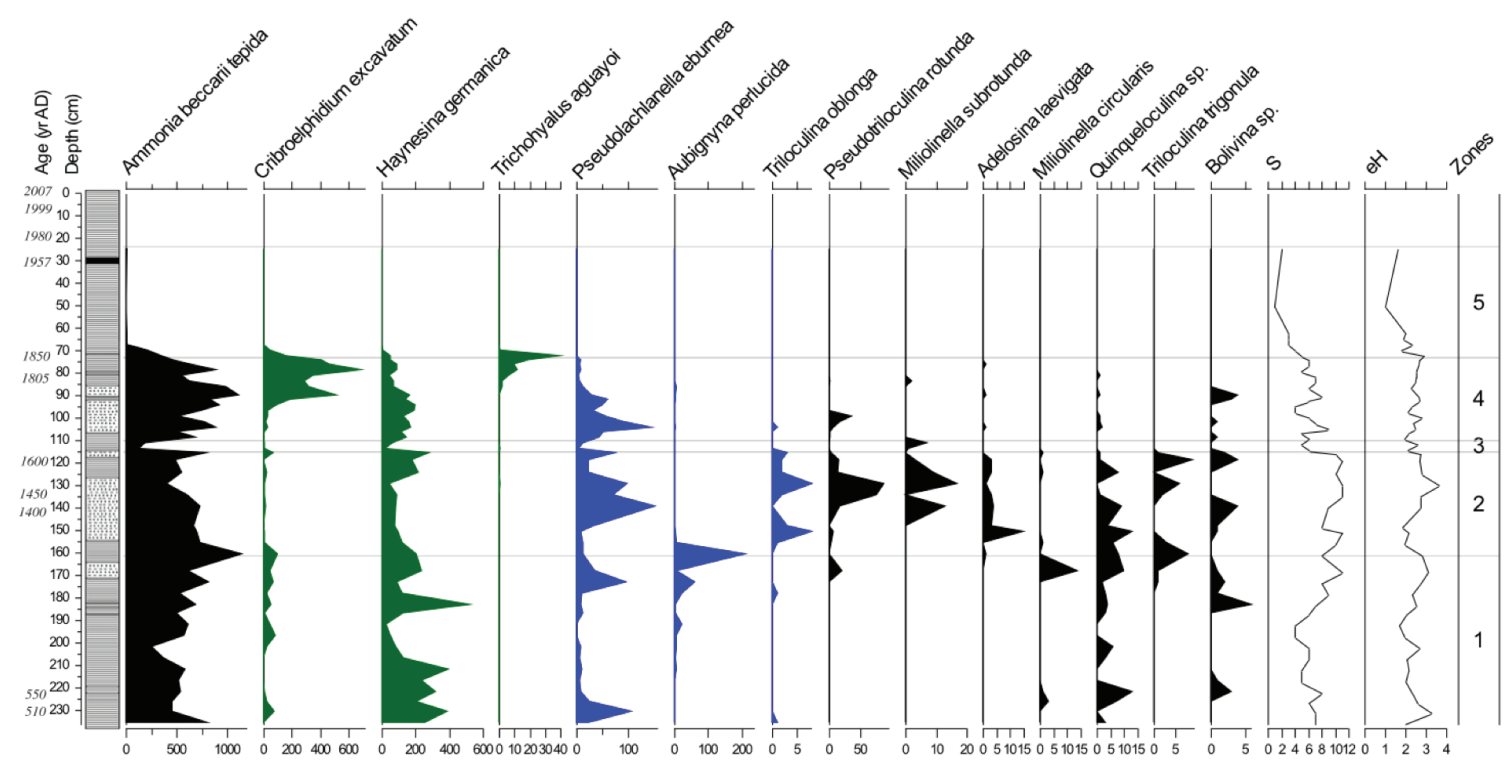

Figure 17. Summary stratigraphic diagram of foraminifera abundances in Lake Albufera core Centre showing taxa present at minimum $>5$ individuals. Green: species tolerant of relatively low salinity in brackish waters (other than Ammonia spp.); blue: those considered less tolerant to low salinity. The diversity of order $0(\mathrm{~S}=$ species richness) and order $1(\mathrm{e} H$, where $\mathrm{H}=\mathrm{Shannon}$ diversity), and zone boundaries defined by constrained cluster analysis are shown on the right. Sediment legend as in figure 2. Gráfico estratigráfico resumen de los foraminiferos del core Centre de la laguna de la Albufera, mostrando las especies con un mínimo de individuos $>$ 5. Verde: especies tolerantes a salinidades relativamente bajas en aguas salobres (aparte de Ammonia spp.); azul: aquellas poco tolerantes a bajas salinidades. A la derecha se muestran la diversidad de orden 0 ( $S=$ riqueza de especies) y orden 1 ( $e^{H}$, donde $H=$ diversidad de Shannon), así como las zonas definidas mediante análisis constreñido de clasificación. Leyenda de la columna sedimentaria como en la figura 2.

cm (Zone 5), with only one or two species present in some samples and at very low abundances (Fig. 17). As in the shorter core Antina, A. tepida, $C$. excavatum and $H$. germanica dominated the sequence. Zone $1(235-161 \mathrm{~cm})$ was relatively species-poor, but progressively increased in richness towards the top, attaining values close to the maxima recorded in the more diverse Zone 2 $(161-114.5 \mathrm{~cm})$. Zone $3(114.5-111.5 \mathrm{~cm})$ is characterized by a sharp and brief decline in abundance and diversity of foraminifera, which partly recover in Zone 4. An important peak in abundance of $C$. excavatum is observed in the top half of Zone 4, which ends abruptly at about $72 \mathrm{~cm}$ with the maximum abundances of T. aguayoi, in close similarity to the top of the foraminiferal sequence of core Antina.

\section{Ostracod assemblages}

We identified 100952 ostracod valves, represent- ing 18 species of ostracods from 15 genera in the Albufera Core Centre sequence. A selection of common species is shown in figure S4. Ostracods were absent from two of the 70 studied samples (at the top of the core), and 6 samples had only one species present (Fig. 18).

Cyprideis torosa together with Loxoconcha elliptica and Xestoleberis nitida were the most abundant species along the core. In addition, Aurila arborescens, Candona angulata and Darwinula stevensoni were also abundant, especially the first one in the lower part of the sequence. Candona angulata and D. stevensoni were abundant in the upper part and Paralimnocythere psammophila, Cypridopsis vidua and Limnocythere innopinata appeared with lower abundances. Other species present were very scarce.

Application of a stratigraphically-constrained cluster analysis to the ostracod assemblages allowed the differentiation of 4 main stratigraphical zones that could be further subdivided onto 7 
different subzones (Fig. 18). The 4 main stratigraphic zones presented different assemblages regarding to their ecological recruitments (1: brackish; 1b: brackish-marine; 2: brackish; 3-4: freshwater).

\section{Ecophenotypic response and isotope composition} of Cyprideis torosa shells

The length of 2110 C. torosa valves (994 females and 1116 males) was measured from 57 subsamples (Fig. 19). LOESS regression was applied separately to female and male size changes through the core and showed that both followed the same pattern of variation in carapace length with depth through the core. Most C. torosa found at zones 1 and 2 showed smooth (unnoded) valves, but the percentage of $C$. torosa noded forms increased in zone 3, suggesting an important salinity decrease.

The isotope values for $C$. torosa shells ranged between $-10.06 \%$ and $2.33 \%$ (mean value -5.45 $\% 0 \pm 1.61)$ for $\delta^{13} \mathrm{C}$ and between $-4.98 \%$ and 3.29 $\%$ (mean value of $-0.18 \% \pm 1.71$ ) for $\delta 180$ (Fig. 19). These two variables were not correlated for the entire sequence. $\delta^{18} \mathrm{O}$ showed high variability among individual valves in zone 1 (235-107), suggesting a mix of waters or evaporation processes during some periods. $\delta^{13} \mathrm{C}$ remained fairly constant along this zone. Notable variation in $\delta^{18} \mathrm{O}$ values occurred in zone $2(107-73 \mathrm{~cm}) . \delta$ ${ }^{13} \mathrm{C}$ increased towards the mid part of this zone (but decreasing in SD) and increased again towards the upper zone boundary. The most important changes were observed for both variables in subzone 3a (73-60 cm; Fig. 19). $\delta 180$ dropped markedly towards the mid part of the subzone, reaching very low values. $\delta^{13} \mathrm{C}$ also showed a decreasing trend, but less marked. $\delta^{13} \mathrm{C}$ was highly variable in subzone $3 \mathrm{~b}(60-39 \mathrm{~cm})$, and the few isotopic shell analyses (2) performed for zone $4 \mathrm{a}$ show values that were somehow lower (but still in the range) as those of subzone $3 b$.

The isotopic results compared with previous data (Marco-Barba et al., 2012b) for recent shells of C. torosa (Fig. S5, available at http://www.limnetica.net/en/limnetica) show that ostracod zones 1 and 2 fitted well within the range of values for typical brackish and hypersaline sites studied by Marco-Barba et al. (2012b). Also $\delta 18 \mathrm{O}$ results for zones 3 and 4 fit values corresponding to low salinity environments as compared with

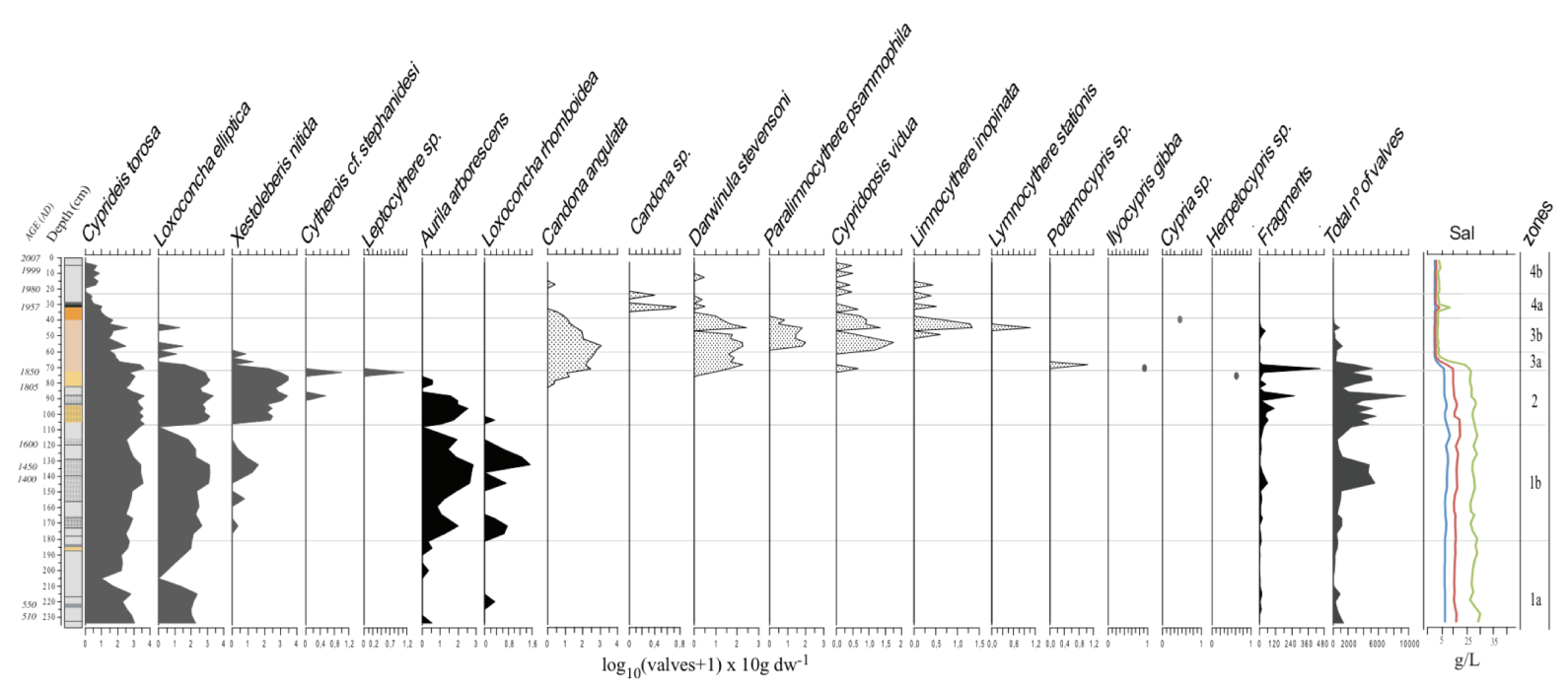

Figure 18. Stratigraphic diagram of ostracod abundances and reconstructed salinity (Sal) in Lake Albufera Core Centre. The zones defined by constrained cluster analysis are also shown. Dark grey: brackish species; black: brackish-marine species; light grey: freshwater species. Diagrama estratigráfico de las abundancias de los ostrácodos y la salinidad estimada (Sal) en el Core Centre de la laguna de la Albufera. Se muestran además las zonas definidas por un análisis de clasificación constreñido. Gris oscuro: especies de aguas salobres; negro: especies con afinidades salobres-marinas; gris claro: especies dulceaqüícolas. 


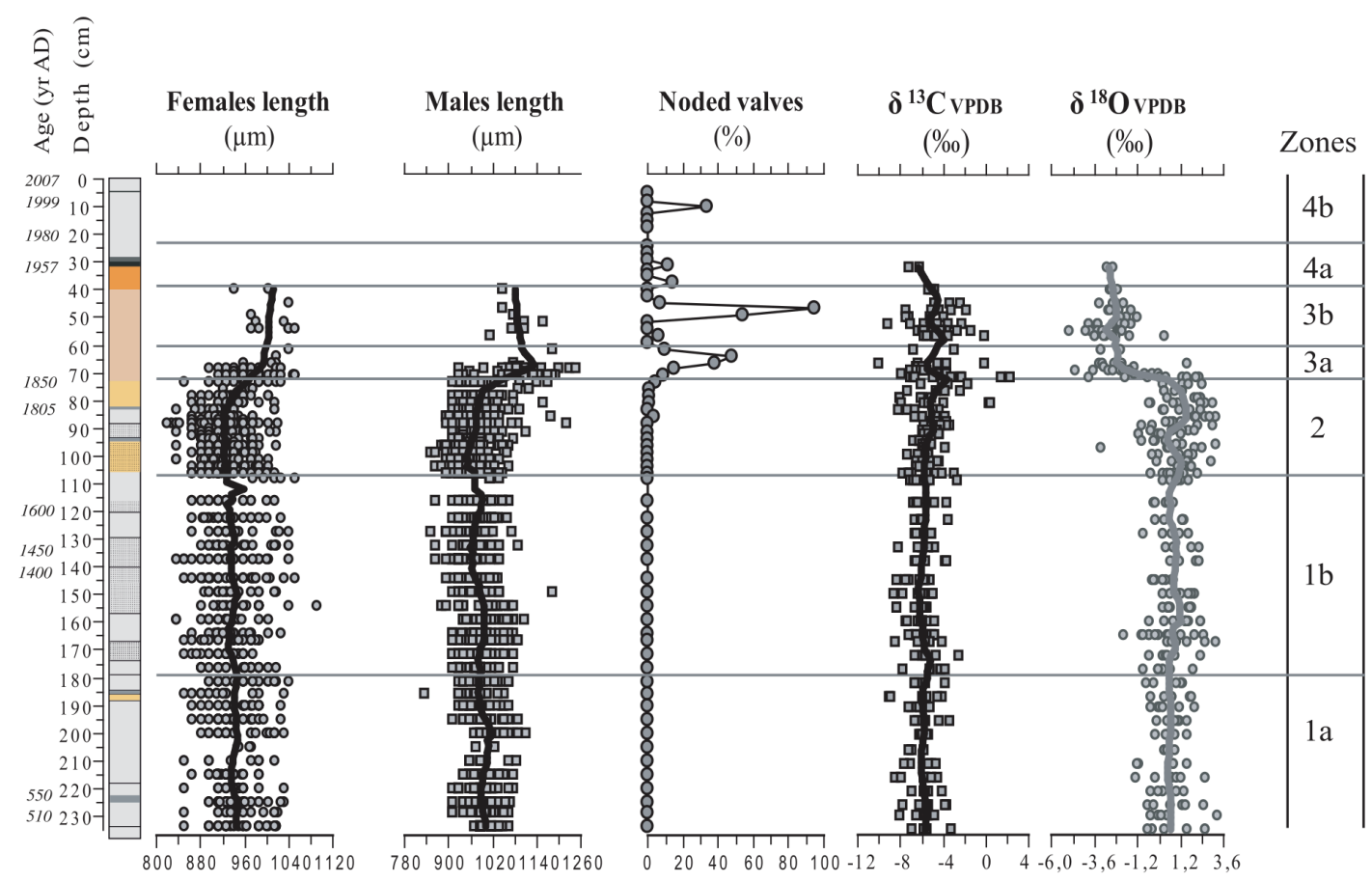

Figure 19. Cyprideis torosa measured carapace lengths for females and males, percentage of noded C. torosa valves and isotopical ratios $\left({ }^{13} \mathrm{C} / 12 \mathrm{C}\right.$ and $\left.18 \mathrm{O} / 16 \mathrm{O}\right)$ performed on $C$. torosa shells along the sedimentary sequence of Core Centre. Loess regressions were performed for all ratios using average scale of 10. Medidas de longitud de las valvas de Cyprideis torosa para machos y hembras, porcentaje de valvas nodadas de $\mathrm{C}$. torosa y razones isotópicas $\left({ }^{13} \mathrm{C} / 12 \mathrm{C}\right.$ and $\left.18 \mathrm{O} / 16 \mathrm{O}\right)$ de las conchas de $\mathrm{C}$. torosa a lo largo de la secuencia sedimentaria del core Centre. Las regresiones Loess se llevaron a cabo para todas las proporciones utilizando una escala promedio de 10.

previous geochemical data on recent ostracods obtained by Marco-Barba et al. (2012b) (Fig. S5). However, the data for $\delta^{13} \mathrm{C}$ values are higher than expected given their $\delta 18 \mathrm{O}$ values, based on relationships defined by Marco-Barba et al. (2012b) in oligohaline spring ponds. This difference is expected from the different origin of water (ground- vs. surface) and by the much highest productivity of a lagoon compared to a spring pond with clear waters (Leng \& Marshall, 2004).

\section{DISCUSSION}

The prehistoric Albufera lagoon (8700 - 3400 cal. BP)

Cores El Palmar and Pujol were extracted from the sand bar separating the lagoon from the sea, and their sedimentary analysis (Santisteban et al., 2009) revealed the major influence of marine transgression and regression events on its depositional history. As reported previously for El Palmar (Marco-Barba et al., 2013a), both sequences are dominated by brackish water ostracod taxa (euryhaline and brackish stenohaline) rather than fully marine, species-rich (e.g. Ruiz et al., 2000) assemblages, indicating that the area was not widely open to the sea during most of the Holocene (Fig. 20). The analysis of foraminifera and diatoms confirm the interpretation, as indicated by the dominance of $A$. beccarii and associated forams, and (where preserved) Mastogloia taxa and other obligate saline brackish diatoms. The exception is in the lower Pujol sequence, where peaks in foraminiferal diversity occur during a phase thought to represent a sandy beach in a transgressive period (Santisteban et al., 2009), suggesting stronger marine influence in the northern part of the recent barrier, which is at present much closer to the seashore than Palmar. 
For the same period, Carmona et al. (2016) also found a brackish lagoon foraminiferal community in the northern part of the Albufera wetland, in a site location occupied by ricefields since the early $19^{\text {th }}$ century.

At about $8300 \mathrm{cal}$. BP, there is a change in the type of sediments (muddy to sandy), and a sharp reduction event in ostracod, foraminiferal and algal remains abundance, coincident with an important peak in megaspores (Fig. 20). Modern megaspores are produced by heterosporous lycopods and ferns (Traverse, 2007), and are considered a proxy for the presence of tall grasses and rushes common on the borders of freshwater and brackish wetlands (Goodman et al., 2008). Therefore, a relative increase may indicate a reduction in the inundated part of the lake in relation to the littoral area. If the chronology is accurate, this event might be related to the 8.2 event (Bond et al., 1997), which could have triggered a reduction of the water table in the wetland at that time. Also, Carmona et al. (2016) relate the base of a sequence from the northwestern part of the lake, which consisted of a peat layer, to a potentially cold and dry period. This period is brief, and ostracod and foraminiferal communities rapidly recover. Subsequently, between about 7500 and 7100 cal. BP, another longer lasted and major reduction
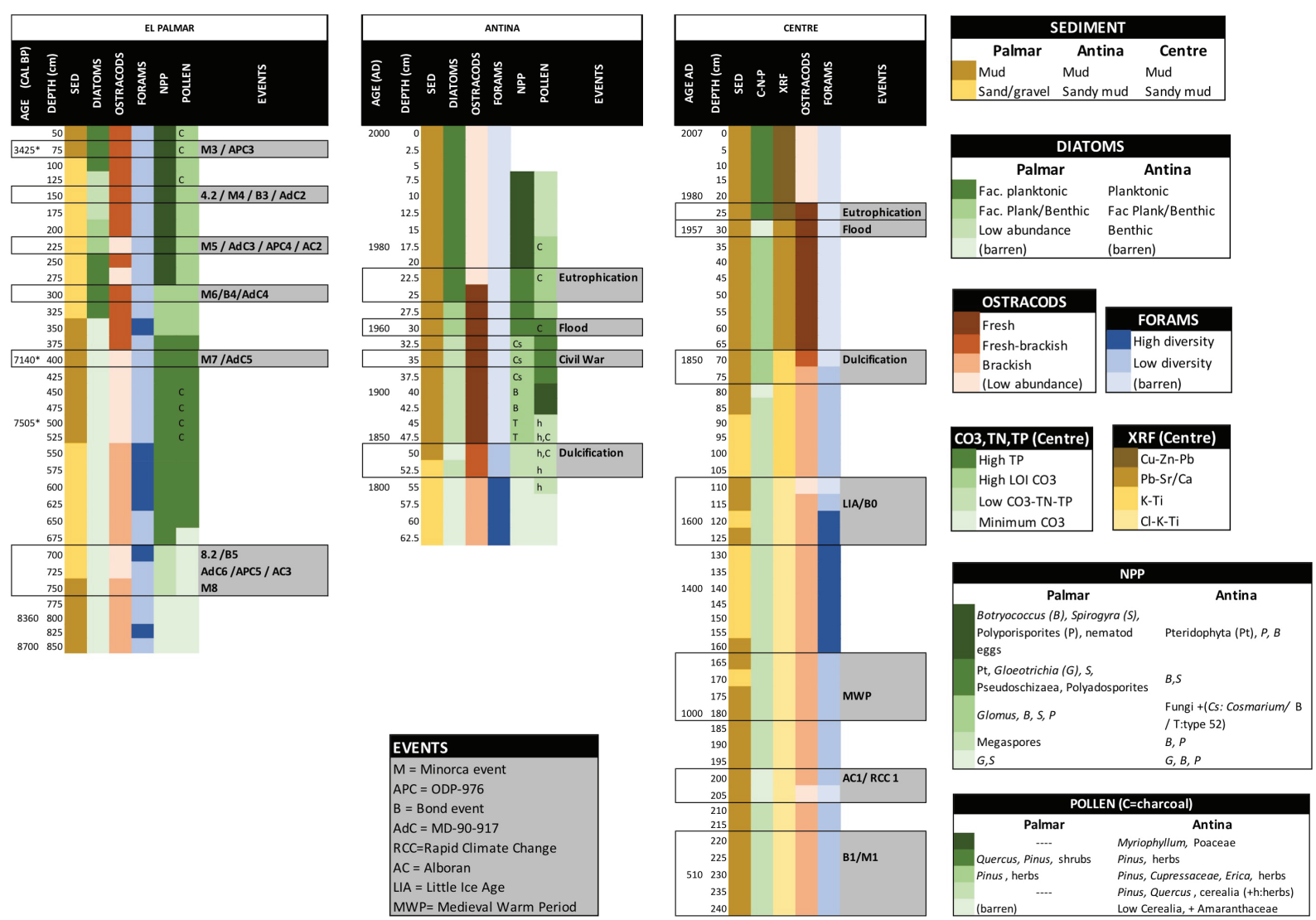

Figure 20. Summary of main changes detected for different proxies in the Albufera de València sequences of El Palmar, Antina and Centre. The chronological location of main events are to be taken as approximate, particularly for Core Palmar, considering the low resolution of the chronology. ${ }^{* 14} \mathrm{C}$ cal. dates; other dates are estimated from the chronological models. See text for further explanations and for more detailed proxy sequences and interpretations. Resumen de los principales cambios detectados para diferentes indicadores de las secuencias de El Palmar, Antina y Centre de la Albufera de València. La localización cronológica de los principales eventos debe considerarse aproximada, particularmente para el core Palmar, teniendo en cuenta la baja resolución de la cronología. * dataciones calibradas ${ }^{14}$ C; otras fechas son estimaciones a partir de los modelos cronológicos. Véase el texto para más explicaciones y mayores detalles de las secuencias de los indicadores y su interpretación. 
in ostracod abundance is recorded, coinciding with a shift in sediment composition, in foraminiferal composition and a reduction in species richness, and the common presence of soil fungal remains (Fig. 8, Fig. 20). This phase also suggests an aridity period, that might correspond to the M7 Minorca event (Frigola et al., 2007), although it could also relate to an inland advance of the sand barrier (aggradation) at the point of core extraction (Santisteban et al., 2009), reducing the lagoon to a series of (temporary) shallow interdune ponds (although no ostracod remains typical of temporary water bodies such as those described by Rueda et al. 2006 were observed).

Above this part of the sequence, proxy data indicate environmental changes that would create a wetland and landscape quite different to its previous state. Indeed the largest palaeoenvironmental change through the El Palmar core is observed at about $4 \mathrm{~m}$ depth (7140 cal. BP) (Fig. 20), when ostracods, diatoms and other algal remains (e.g. Botryococcus, Gloeotrichia, Spirogyra) start to show a more stable oligohaline (see e.g. Margalef, 1983) water body from here on. Diatoms are preserved for the first time at $312 \mathrm{~cm}$ depth, indicative of a shallow, brackish, environment. The salinity optimum of $P$. brevistriata is quite high because it will tolerate brackish water but it also occurs in fresh water, as do all of the facultative planktonic taxa encountered. The maximum abundance of these taxa in zone 1 $(341.5-251.5 \mathrm{~cm})$ could indicate lower salinity but is difficult to interpret. Shifts between facultative planktonic and benthic diatom taxa could also result from changes in water depth, but (in the absence of true plankton) are more likely to indicate changes in the proportion of reeds (FP) to $\mathrm{mud} /$ stone habitat. Ostracod palaeoassemblages and ecomorphogenetic changes provide more definitive evidence for lower salinity at the top of the sequence (Marco-Barba et al., 2013a), but always in the oligohaline-mesosaline range. The reasons for intermittent diatom preservation are not clear; since there is no evidence for hypersalinity in samples containing sparse assemblages, it is more likely to be a function of a high energy environment (breakage and poor burial) in the turbid, shallow water of the littoral zone; the complete absence of diatoms at the base of the sequence may be a function of low productivity prior to erosion of nutrients into the lake with deforestation (as suggested by pollen remains see below), or could reflect more rapid burial with enhanced sediment input.

But not only major changes in the functioning of the water body are found, as also we observe major shifts in landscape vegetation, as suggested by palynological data. Prior to $7140 \mathrm{cal}$. BP, the vegetation was dominated by trees (Quercus) and bushes (Erica, Cistus), but above the layer that might indicate the M7 event (Frigola et al., 2007), Poaceae (including Cerealia-type) dominate, suggesting a major climate change effect towards higher aridity, although this contrasts with the western Mediterranean increased precipitation at about 6000 BP suggested by general models (Roberts et al., 2011), so as with the reduction in salt content in the lake as suggested by microfossils. Vegetation changes coincide with a change in the depositional environment (lagoonal to sandy lobes), so that the palynological change observed might also be related to the local development of grasses in these new sandy environments. Further decreases in arboreal pollen through the top half of the sequence are also coeval with known aridity events (M3-M6; Frigola et al., 2007).

We cannot however rule out the potential influence of human impact on landscape changes at these early times. A hint to these effects is the frequency above $350 \mathrm{~cm}$ of egg cover remains of parasitic worms (Nematoda), probably related to increased cattle raising activities around the lake. Fire events (charcoal frequency) had already increased prior to deforestation, but charcoal remains subsequently increased in frequency in the top half of the sequence. Human populations are known to have occupied the territory near the lake (a few $\mathrm{km}$ inland and tens of $\mathrm{km}$ southward) and had used its resources (e.g. cockles, grain) at least since about 6000 BP (Mateu et al., 1985; Martí-Oliver, 1988). Not too far, at about 50-70 $\mathrm{km}$ to the south, major vegetation changes during this period have been suggested to be human-induced through fires (Carrión \& van Geel, 1999; Carrión et al., 2010), and increased livestock activities at around $6200 \mathrm{cal}$. BP have been associated to forest decline near Neolithic settlements (Dupré, 1995; Badal et al., 2012). 


\section{The historic Albufera lake (500 AD- 2007)}

Unfortunately, according to the chronology of our cores, we have no data for palaeoenvironmental change between 3400 and 1500 cal. BP in the Albufera lagoon. However, a sequence analysed by Carmona et al. (2016) from the northwestern part of the wetland includes this period. These authors found no major difference in foraminiferal species composition from the oldest sediments, since c. 8200 up to 1000 cal BP, being dominated by $A$. tepida, $H$. germanica and $C$. excavatum, indicating a brackish coastal lagoon. This association is very similar to that found dominating the base of our shortest core Antina and most of the longer Core Centre.

The bottom half of Core Centre shows in general homogeneous traits in many proxies (Fig. 20 ), including elements detected by XRF, magnetic susceptibility, LOI, N and P content, ostracod geochemistry and shell size of C. torosa, so as in dominant species of ostracods (C. torosa, $L$. elliptica) and foraminifera (A. tepida, H. german$i c a$ ). Still, some striking events can be observed and interpreted. First, there is an unusually rapid shift in various elements that decrease at 210-215 $\mathrm{cm}$ and increase to high values at $200-205 \mathrm{~cm}$ (an approximate estimated age of 700-800 AD) (Fig. 16). These include minimum values (and subsequent peaks) of $\mathrm{K}, \mathrm{Ti}, \mathrm{Al}, \mathrm{S}, \mathrm{Ca}, \mathrm{Cl}, \mathrm{Si} / \mathrm{Ca}$ and inverted peaks in $\mathrm{Sr} / \mathrm{Ca}$. At the same point, there is a minor peak in magnetic susceptibility and minimum values in carbonate content. Also, the stratigraphy shows a remarkable absence of macroremains and a sudden drop in ostracod and foraminiferan abundance (Fig. 20). A potential explanation could be a flood event (increased sediment input and reduced density of shell remains) or some sort of rapid climate change. At this time, Moberg et al. (2005) found a peak in global temperature after a cold period. The established arid periods AC1 (Alborán events; Cacho et al., 2001) and RCC1 (Rapid Climatic Change periods; Mayewski et al., 2004) might also be responsible for such a rapid event. Unfortunately, we have no pollen data from this core to see if vegetation suffered some change at this time to validate this hypothesis. Another change in the lower sequence, from $180-160 \mathrm{~cm}$ (i.e.
1000-1200 yr AD), occurs when brackish (and some marine) ostracods and foraminifera increase progressively in abundance and diversity indicating more stable conditions in a brackish lagoon, at the time of the Medieval Warm Period. Later on, at about $1700 \mathrm{AD}(110 \mathrm{~cm}$ depth), another sudden drop in ostracod and foraminifer abundance and diversity occur, probably related to reduced productivity at low temperatures during the Little Ice Age (although our chronological model has to be taken with caution).

The most important change through the last 1500 years in the lake record is observed at a depth of $70-75 \mathrm{~cm}$ in the Core Centre, and 50-55 $\mathrm{cm}$ in core Antina (Marco-Barba et al., 2013b for ostracods, and this survey for other remains), both corresponding to the beginning of the 19th century. Here, the system changes completely from a brackish to an oligohaline lagoon. Diatoms and cladocerans (Marco-Barba et al., 2012a) start to be common, while foraminifera disappear, at the same time that the ostracod palaeocommunity shifts from one dominated by unnoded, small, C. torosa and accompanying brackish species to one with noded and larger $C$. torosa and typical freshwater dwellers. Ostracod shell $\delta 18 \mathrm{O}$ drops and $\mathrm{Sr} / \mathrm{Ca}$ values increase (Marco-Barba et al., 2013b). Altogether this indicates a reduction in salinity from about 15 to less than $2 \mathrm{~g} / \mathrm{L}$ (Marco-Barba et al., 2013b). K, Ti, Al and $\mathrm{S}$ drop, and $\mathrm{Pb}, \mathrm{Cr}$ and $\mathrm{Ba}$ increase, together with LOI, carbonates and $\mathrm{N}$ content. An initial increase in $\mathrm{S} / \mathrm{Cl}$ may suggest increased sulphide (Zwolsman et al., 1993) at the start of the freshening phase, probably indicating biomass decomposition at the collapse of the brackish adapted communities. The most intense human impact occurred during this period. The Spanish crisis at the beginning of the XIX century and the changes in the property of the surrounding land leaded to intensive agricultural expansion and to strong hydrological control of the Albufera de Valencia (Sanchis Ibor, 2001; Marco-Barba et al., 2012; 2013b). The lagoon area was reduced in $6000 \mathrm{Ha}$ and became hydrologically controlled for rice farming (Mateu, 1987; Sanchis Ibor, 2001). This increase in rice cultivated area may correspond to the pollen local signal of increased Cerealia-type remains in the Antina core, co-occurring with the 
reduction in Amaranthaceae, indicators of more saline environments.

As a response to this drastic salinity change, the macrophyte community also switched from dominance by salt tolerant species such as Lamprothamnium papulosum (Wallroth) or Chara aspera Detharding ex Willdenow to freshwater species including $C$. vulgaris L., C. tomentosa L. and $C$. hispida L., as shown by previous research (Rodrigo et al., 2010; Rodrigo \& Alonso-Guillén, 2013), and including Myriophyllum sp., as indicated by the peak in our pollen data. The core depth of this freshening and the age model (based on $210 \mathrm{~Pb}-137 \mathrm{Cs}$ dating) provided by Rodrigo et al. (2010) fit very closely to our results. In contrast, Carmona et al. (2016) found that freshening took place much earlier, at about 820 cal. $\mathrm{BP}$ according to their ${ }^{14} \mathrm{C}$ dates. Notwithstanding potential chronological uncertainties, a possible explanation of these large differences might come from wetland spatial heterogeneity, as the site in Carmona et al. (2016) is much further inland and close to a ravine, which could have promoted the change to an oligohaline wetland in that area during wettest periods and/or with reduced flow connections with the main lagoon water body (i.e. it might be flowing only downstream to the central lake but not backwards, unless the site was fully open to the lake and wind could easily mix the waters).

At the beginning of the 20th century, the palaeolimnological data and geochemistry show no major changes (other than increased LOI and $\mathrm{N}$ content, related to the development of a macrophyte meadow and increased trophic state; Marco-Barba et al., 2012a) but the pollen and NPP remains start to change, indicating a certain recovery of forested (Pinus spp.) areas, partially interrupted shortly during a time corresponding approximately to the Spanish Civil War (1936-1939). At the point when expanding forests retreat again (maybe because of logging for winter heating or cooking), an increase in Cyperaceae and Poaceae occurs, perhaps related to more intense use of wet areas surrounding the lagoon for cattle raising (Plantago in zone B1, Fig. 12, and Polyadosporites in zone A2, Fig. 13; López-Sáez and López-García, 2003), a longstanding practice since at least the late $13^{\text {th }}$ centu- ry (Rosselló i Verger, 1995) which is known to have continued during the $16^{\text {th }}$ century (Sanchis Ibor, 2001), though perhaps reduced after ricefield expansion.

At the end of the first half of the 20th century, despite the huge ecosystem change, the water quality of the lake was still high, with a well-developed macrophyte community and rich in benthic and planktonic groups indicative of clear waters (Pardo, 1942; Fundació d'Amics del Parc Natural de L'Albufera, 2000). This is in agreement with the observed peak in chlorophytes with a preference for oligotrophic waters such as Cosmarium (see Margalef, 1983) in the Antina core. However, nutrient input to the lake continued to rise, particularly $\mathrm{P}$, and Cosmarium started to be replaced by more tolerant groups such as Botryococcus or Spirogyra (Margalef, 1983).

By the end of the 60's and during the early 70 's, an increase in human population, urban development and industrialisation, would definitely drive another major change in the lake towards its present hypereutrophic and polluted state, indicated by the diatom Cyclotella meneghiniana, for example. The lagoon was heavily artificially modified by this time. The previous rice field expansion had already caused a reduction of the area of the lake, with extensive use of fertilizers. Fine mud sediments, the absence of mollusc shells and macrophyte remains, reduced ostracod density and a major change in diatom composition favouring planktonic species, characterized this period. The reduction in benthic organisms (ostracods and diatoms) was driven by poor water quality, the loss of macrophytes and the anoxic conditions at the bottom sediments (Marco-Barba et al., 2012a), coupled with increased productivity. The uncontrolled watersheds, agricultural residues and industrial spills into the lake modified the natural conditions of the system driving it to an hypereutrophic state. The collapse of macrophytes in a hypereutrophic system coincides with a prolonged peak in sediment sulphide (as $\mathrm{S} / \mathrm{Cl}$ ), added to pollution by heavy metals $(\mathrm{Pb}, \mathrm{Cr}, \mathrm{Zn})$ and, consequently, to low water quality and the loss of biodiversity (Vicente \& Miracle, 1992; Romo et al., 2005; Poquet et al., 2008; Marco-Barba et al., 2013b). Hopefully, the effects of sewage diversion on 
reducing nutrient load into the lake (Soria, 2006) might drive a future drop in the trophic conditions of Albufera and perhaps some recovery of the previously diverse benthic community.

\section{ACKNOWLEDGEMENTS}

The former Spanish Ministry of Education and Technology funded this research through the project VARECOMED (REN2002-03272). JMB acknowledges the funding from a fellowship (BES-2003-2759) as part of the VARECOMED project. We thank also Blas Valero and Ana Moreno and the people from University of Minnesota, Limnological Research Centre and Lac Core who helped on the laboratory core descriptions. M.A. Rodrigo assisted in the interpretation of macrophyte changes. JMB wants to dedicate the paper to the memory of his grandparents, Carmen Polo and Jose Barba, for their support and advice, and who died during the development of this work. Patrícia Llàcer-Manrique collaborated in the palynological analysis. We would like to thank two anonymous reviewers for their thoroughly effort in suggesting improvements to an early version of the manuscript. Finally, all living authors would like to acknowledge the great interest of the deceased senior author, Maria Rosa Miracle, for her perseverance in pursuing understanding of natural phenomena and for the conservation of nature.

\section{REFERENCES}

ANDERSEN, S. T. 1978. Identification of wild grasses and cereal pollen. Danmarks Geologiske Undersogelse, Arbog, 1978: 69-92.

APHA. 1992. Standard methods for the examination of water and waste water. 18th American Public Health Association (ed.), Washington, DC.

APPLEBY, P. G. \& F. OLDFIELD. 1978. The calculation of lead-210 dates assuming a constant rate of supply of unsupported $210 \mathrm{~Pb}$ to the sediment. Catena, 5(1): 1-8. DOI: 10.1016/S0341-8162(78)80002-2

ATHERSUCH, J., D. J. HORNE \& J. E. WHITTAKER. 1989. Marine and Brackish water ostracods. Brill, E.J. London.
BADAL, E., B. MARTÍ OLIVER \& M. PÉREZ-RIPOLL. 2012. From agricultural to pastoral use: changes in Neolithic landscape at Cova de l'Or (Alicante, Spain). Sagvuntvm Extra, 13: 75-84.

BATTARBEE, R. W., S. JUGGINS, F. GASSE, N. J. ANDERSON, H. BENNION \& N. G. CAMERON. 2000. European Diatom Database (EDDI). An information system for palaeoenvironmental reconstruction. European Climate Science Conference, Vienna, Austria: $1-10$.

BATTARBEE, R. W., V. J. JONES, R. J. FLOWER, N. G. CAMERON \& H. BENNION. 2001. Diatoms. In: Tracking Environmental Change Using Lake Sediments, Terrestrial, Algal, and Siliceous Indicators, vol. 3. Smol, J.P., Birks, H.J.B., Last, W.M. (Eds.): 155 - 202. Kluwer Academic Publishers, Dordrecht, Netherlands. DOI: 10.1007/ 0-306-47668-1

BEN KHELIFA, L. 1989. Diatomées continentales et paléomilieu du Sud-Tunisien (Palhydaf Site 1) au Quaternaire supérieur. Approche statistique basée sur les diatomées et les milieu naturels. Ph.D. Thesis. Univ. Paris-Sud.

BERNABEU, J., O. GARCÍA PUCHOL, S. PARDO, M. BARTON \& S. B. MCCLURE. 2014. Socioecological dynamics at the time of Neolithic transition in Iberia. Environmental Archaeology, 19 (3): 214-225. DOI: 10.1179/ 1749631414Y.0000000032

BERNABEU-AUBÁN， J., O. GARCÍA-PUCHOL, M, BARTON, S. MCCLURE \& S. PARDO-GORDÓ. 2016. Radiocarbon dates, climatic events, and social dynamics during the Early Neolithic in Mediterranean Iberia. Quaternary International, 403: 201-210. DOI: 10.1016/j.quaint.2015.09.020

BEUG, H.-J. 2015. Leitfaden der Pollenbestimmung für Mitteleuropa und angrenzende Gebiete. Verlag Dr. Friedrich Pfeil, München. BINDLER R., R. INGEMAR \& J. KLAMINDER. 2008. Bridging the gap between ancient metal pollution and contemporary biogeochemistry. Journal of Paleolimnology, 40: 755-770. DOI: 10.1007/s10933-008-9208-4

BINFORD, M. W. 1990. Calculation and uncer- 
tainty analysis of $210 \mathrm{~Pb}$ dates for PIRLA project lake sediment cores. Journal of Paleolimnology, 3(3): 253-267. DOI: 10.1007/ BF00219461

BLÁZQUEZ, A. M. \& J. USERA. 2010. Palaeoenvironments and Quaternary foraminifera in Elx coastal lagoon (Alicante, Spain). Quaternary International, 221:68-90. DOI: 10.1016/j.quaint.2009.06.033

BLÁZQUEZ, A. M., A. RODRÍGUEZ-PÉREZ, T. TORRES \& J. E. ORTIZ. 2017. Evidence for Holocene sea level and climate change from Almenara marsh (Western Mediterranean). Quaternary Research, 88: 206-222. DOI: 10.1017/qua.2017.47

BOND, G., W. SHOWERS, M. CHESEBY, R. LOTTI, P. ALMASI, P. B. DEMENOCAL, P. PRIORE, H. CULLEN, I. HAJDAS \& G. BONANI. 1997. A Pervasive Millennial-Scale Cycle in North Atlantic Holocene and Glacial Climates. Science, 278: 1257-1265. DOI: 10.1126/science.278.5341.1257

BOYLE, J. F. 2000. Rapid elemental analysis of sediment samples by isotope source XRF. Journal of Paleolimnology, 23: 213-221. DOI: 10.1023/A:100805350

BURJACHS, F., J. A. LÓPEZ-SÁEZ \& M. J. IRIARTE. 2003. Metodología arqueopalinológica. In: La recogida de muestras en arqueobotànica: objetivos y propuestas metodológicas. Buxó, R. \& R. Piqué (coords.): 11-18. Museu d'Arqueologia de Catalunya, Barcelona.

BURJACHS, F. \& I. EXPÓSITO. 2015. Charcoal and pollen analysis: Examples of Holocene fire dynamics in Mediterranean Iberian Peninsula. Catena, 135: 340-349. DOI: 10.1016/j. catena.2014.10.006

CACHO, I., J. O. GRIMALT, M. CANALS, L. SBAFFI, N. J. SHACKLETON, J. SCHOENFELD \& R. ZAHN. 2001. Variability of the western Mediterranean Sea surface temperature during the last 25,000 years and its connection with the Northern Hemisphere climatic changes. Paleoceanography, 16 (1): 40-52. DOI: 10.1029/2000PA000502

CARMONA, P. \& J. M. RUIZ. 1999. Evolución en el Holoceno reciente del delta del río Turia y la restinga de la Albufera de Valencia. In:
Geoarqueologia $i$ Quaternari litoral. Homenaje a Maria Pilar Fumanal. Rosselló, V. (ed.): 321-331. Universitat de València, València.

CARMONA, P. \& J. M., RUIZ. 2000. Las inundaciones de los ríos Júcar y Turia. Serie Geográfica, 9: 49-69.

CARMONA, P., J. M. RUIZ-PÉREZ, A. M. BLÁZQUEZ, M. LÓPEZ-BELZUNCE, S. RIERA \& H. ORENGO. 2016. Environmental evolution and mid-late Holocene climate events in the Valencia lagoon (Mediterranean coast of Spain). Holocene, 26: 1750-1765. DOI: $10.1177 / 0959683616645940$

CARRIÓN, J. S. \& B. VAN GEEL. 1999. Fine-resolution Upper Weichselian and Holocene palynological record from Navarrés (Valencia, Spain) and a discussion about factors of Mediterranean forest succession. Review of Palaeobotany and Palynology, 106: 209-236. DOI: 10.1016/S0034-6667(99)00009-3

CARRIÓN, J. S., S. FERNÁNDEZ, P. GONZÁLEZ-SAMPÉRIZ, G. GIL-ROMERA, E. BADAL, Y. CARRIÓN-MARCO, L. LÓPEZ-MERINO, J. A. LÓPEZ-SÁEZ, E. FIERRO \& F. BURJACHS. 2010. Expected trends and surprises in the Lateglacial and Holocene vegetation history of the Iberian Peninsula and Balearic Islands. Review of Palaeobotany and Palynology, 162 (3): 458-475. DOI:10.1016/j.revpalbo.2009.12.007 CAVANILLES, A. J. 1795. Observaciones sobre la Historia Natural, Geografía, Agricultura, Población y Frutos del Reyno de Valencia. Imprenta Real, Madrid.

COHEN, A. S. 2003. Paleolimnology: the history and evolution of lake systems. Oxford University Press, New York.

COULARIS, C., N. TISNÉRAT-LABORDE, L. PASTOR, F. SICLET \& M. FONTUGNE. 2016. Temporal and spatial variations of freshwater reservoir ages in the Loire River watershed. Radiocarbon, 58(3): 549-563. DOI: $10.1017 /$ RDC.2016.36

DUPRÉ, M. 1995: Cambios paleoambientales en el territorio valenciano. La palinología. In: $E l$ Cuaternario del País Valenciano: 205-216. Departament de Geografía. Universitat de Valencia. 
EAKINS, J. D. \& R. T. MORRISON. 1978. A new procedure for the determination of lead-210 in lake and marine sediments. The International Journal of Applied Radiation and Isotopes, 29: 531-536. DOI: 10.1016/ 0020-708X(78)90161-8

FAEGRI, K. \& J. IVERSEN. 1989. Textbook of Pollen Analysis (revised by). 4th ed. Faegri, K., P.E. Kaland \& K. Krzwinski (eds.) Wiley, Chichester.

FAROOQ J., L. SCHÜLER \& H. BEHLING. 2015. Trends of pollen grain size variation in C3 and C4 Poaceae species using pollen morphology for future assessment of grassland ecosystem dynamics, Grana, 54(2): 129-145. DOI: $10.1080 / 00173134.2014 .966754$

FERREE, M. A. \& R. D. SHANNON. 2001. Evaluation of a second derivative UV/visible spectroscopy technique for nitrate and total nitrogen analysis of waste water samples. Water Research, 35: 327-332. DOI: 10.1016/S00431354(00)00222-0

FRENZEL, P., I. SCHULZE \& A. PINT. 2012. Noding of Cyprideis torosa valves (Ostracoda) - a proxy for salinity? New data from field observations and a long-term microcosm experiment. International Review of Hydrobiology, 97: 314-329. DOI: 10.1002/ iroh.201211494

FRIGOLA, J., A. MORENO, I. CACHO, M. CANALS, F. J. SIERRO, J. A. FLORES, J. O. GRIMALT, D. A. HODELL \& J. H. CURTIS. 2007. Holocene climate variability in the western Mediterranean region from a deepwater sediment record. Paleoceanography, 22 (2): 1-16. DOI: 10.1029/2006PA001307

FUNDACIÓ D'AMICS DEL PARC NATURAL DE L'ALBUFERA, 2000. El Parc Natural de l'Albufera. Universitat de València, València. GOEURY, C. \& J. L. de BEAULIEU. 1979. À propos de la concentration du pollen à l'aide de la liqueur de Thoulet dans les sédiments minéraux. Pollen et Spores, 21 (1-2): 239-251.

GOODMAN, B., E. REINHARDT, H. DEY, J. BOYCE, H. SCHWARCZ, V. SAHOGLU, H. ERKANAL \& M. ARTZY. 2008. Evidence for Holocene marine transgression and shoreline progradation due to barrier development in Iskele, Bay of Izmir, Turkey. Journal of Coastal Research, 245:1269-1280. DOI: $10.2112 / 06-0811.1$

GOY, J. L., C. ZAZO \& J. D. DABRIO. 2003. A beach-ridge progradation complex reflecting periodical sea-level and climate variability during the Holocene (Gulf of Almería, Western Mediterranean). Geomorphology, 50: 251-268. DOI: 10.1016/S0169-555X(02)00217-9

GRIFFITHS H. I. \& J. A. HOLMES. 2000. Non-marine Ostracods and Quaternary Paleoenvironments (Technical Guide $N^{o} 8$ ). Quaternary Research Association: London.

GRIMM, E. C. 1991-2015. Tilia, version 2.0.41 http://www.tiliait.com

GRIMM, E. C. 1987. CONISS: A FORTRAN 77 program for stratigraphycally constrained cluster analysis by the method of incremental sum of squares. Computers \& Geosciences, 13: $13-35$.

HEIRI, O., A. F. LOTTER \& G. LEMCKE, 2001. Loss on ignition as a method for estimating organic and carbonate content in sediments: reproducibility and comparability of results. Journal of Paleolimnology, 25: 101-110. DOI: 10.1023/A:1008119611481

HUGHEN, K. A., M. G. L. BAILLIE, E. BARD, J. W. BECK, C. J. H. BERTRAND, P. G. BLACKWELL, C. E. BUCK, G. S. BURR, K. B. CUTLER, P. E. DAMON, R. L. EDWARDS, R. G. FAIRBANKS, M. FRIEDRICH, T. P. GUILDERSON, B. KROMER, G. MCCORMAC, S. MANNING, C. BRONK RAMSEY, P. J. REIMER, R. W. REIMER, S. REMMELE, J. R. SOUTHON, M. STUIVER, S. TALAMO, F. W. TAYLOR, J. VAN DER PLICHT \& C. E. WEYHENMEYER. 2004. Marine04 marine radiocarbon age calibration, 0-26 cal kyr BP. Radiocarbon, 46(3): 1059-1086. DOI: $10.1017 / \mathrm{S} 0033822200033002$

ITO, E. 2001. Application of stable isotope techniques to inorganic and biogenic carbonates. In: Tracking Environmental Change Using Lake Sediments., Vol. 2. Physical and Chemical Techniques. Last, W.M. \& J.P. Smol (eds.). Kluwer Academic Publishers. DOI: 10.1007/0-306-47670-3

JOLY, C., L. BARILLÉ, M. BARREAU, A. 
MANCHERON \& L. VISSET. 2007. Grain and annulus diameter as criteria for distinguishing pollen grains of cereals from wild grasses. Review of Palaeobotany and Palynology, 146 (1-4): 221-233. DOI: 10.1016/j.revpalbo.2007. 04.003

JOST, L. 2006. Entropy and diversity. Oikos, 113(2): 363-375. DOI: 10.1111/j.2006.00301299.14714.x

JUGGINS, S. 2007. C2 Version 1.5 User guide. Software for ecological and palaeoecological data analysis and visualisation. Newcastle University, Newcastle upon Tyne, UK.

KRAMMER, K. \& H. LANGE-BERTALOT. 1986, 1988, 1991a, 1991b. Süsswasserflora von Mitteleuropa. Bacillariophyceae. Vols. 2/1, 2/2, 2/3, 2/4. Gustav Fischer Verlag, Stuttgart.

LENG, M. J. \& J. D. MARSHALL. 2004. Palaeoclimate interpretation of stable isotope data from lake sediment archives. Quaternary Science Reviews, 23 (7-8): 811-831. DOI: 10.1016/j.quascirev.2003.06.012

LÓPEZ-BUENDÍA, A. M, J. BASTIDA, X. QUEROL \& M. K. G. WHATELEY. 1999. Geochemical data as indicators of palaeosalinity in coastal organic-rich sediments. Chemical Geology, 157: 235-254. DOI: 10.1016/S0009-2541(98)00207-1

LÓPEZ-SÁEZ, J. A. \& P. LÓPEZ-GARCÍA. 1999. Rasgos paleoambientales de la transición Tardiglaciar-Holoceno (16-17.5 ka BP) en el Mediterráneo ibérico, de Levante a Andalucía. In: Geoarqueologia i Quaternari litoral. Homenaje a Maria Pilar Fumanal. Rosselló V (ed.): 139-152. Universitat de València, València.

LÓPEZ-SÁEZ, J. A. \& P. LÓPEZ-GARCÍA. 2003. Pollen Analysis from Early and Middle Holocene Archaeological Sites in the Blue Nile Area, Central Sudan. Complutum, 14: 397-400.

LOUBLIER, Y. 1978. Application de l'analyse pollinique à l'étude du paléoenvironnement du remplissage Würmien de la grotte de L'Arbreda (Espagne). Académie de Montpellier, Université des Sciences et Techniques du Languedoc, Montpellier.

MARCO, J., 2010. Ecología y geoquímica de ostrácodos como indicadores paleoambientales en ambientes marginales marinos: un ejemplo de estudio, la Albufera de Valencia. Ph.D. Thesis, Universitat de València.

MARCO-BARBA, J., F. MESQUITA-JOANES \& M. R. MIRACLE. 2012a. L'evolució de l'Albufera escrita en els sediments. In: La Universitat de València $i$ els seus entorns naturals: 20-23. Universitat de València, València.

MARCO-BARBA, J., E. ITO, E. CARBONELL \& F. MESQUITA-JOANES. 2012b. Empirical calibration of shell chemistry of Cyprideis torosa (Jones, 1850) (Crustacea: Ostracoda). Geochimica et Cosmochimica Acta, 93: 143-163. DOI: 10.1016/j.gca.2012.06.019

MARCO-BARBA, J., J. A. HOLMES, F. MESQUITA-JOANES \& M. R. MIRACLE. 2013a. The influence of climate and sea-level change on the Holocene evolution of a Mediterranean coastal lagoon: evidence from ostracod palaeoecology and geochemistry. Geobios, 46: 409-421. DOI:10.1016/j.geobios.2013.05.003

MARCO-BARBA, J., F. MESQUITA-JOANES \& M. R. MIRACLE. 2013b. Ostracod palaeolimnological analysis reveals drastic historical changes in salinity, eutrophication and biodiversity loss in a coastal Mediterranean lake. The Holocene, 23(4): 556-567. DOI: 10.1177/ 0959683612466752

MARGALEF, R. 1983. Limnología. Ediciones Omega, S.A., Barcelona.

MARGALEF, R. \& M. MIR. 1973. Indicadors de canvis de salinitat en els sediments de 1'Albufera de València. Treballs Societat Catalana de Biologia, 32: 111-117.

MARTÍ-OLIVER, B. 1988. El nacimiento de la agricultura. El Neolítico: los primeros agricultores. In: Historia del Pueblo Valenciano, vol. 1. Cerdá, M. (Dir.) : 21-30. Ed. Levante.

MATEU, E. 1987. Arroz y paludismo. Riqueza y conflictos en la sociedad valenciana del siglo XVIII. Edicions Alfons el Magnànim. Valencia.

MATEU, J. F., B. MARTÍ OLIVER, F. ROBLES CUENCA \& J. D. ACUÑA HERNÁNDEZ. 1985. Paleogeografía litoral del Golfo de Valencia durante el Holoceno inferior a partir de yacimientos prehistóricos. In: Pleistoceno y Geomorfología litoral. Homenaje a Juan 
Cuerda: 77-101. Universidad de València.

MAYEWSKI, P. A., E. E. ROHLING, J. C. STAGER, W. KARLEN, K. A. MAASCH, L. D. MEEKER, E. A. MEYERSON, F. GASSE, S. VAN KREVELD, K. HOLMGREN, J. LEE-THORP, G. ROSQVIST, F. RACK, M. STAUBWASSER, R. R. SCHNEIDER \& E. J. STEIG. 2004. Holocene climate variability. Quaternary Research, 62 (3): 243-255. DOI: 10.1016/j.yqres.2004.07.001

MEISCH, C. 2000. Freshwater Ostracoda of the Western and Central Europe. (Süßwasserfauna von Mitteleuropa 8/3). Spektrum Akademischer Verlag, Heildeberg.

MEZQUITA, F., V. OLMOS \& R. OLTRA. 2000. Population ecology of Cyprideis torosa (Jones, 1850) in a hypersaline environment of the Western Mediterranean (Santa Pola, Alacant) (Crustacea: Ostracoda). Ophelia, 53(2): 119-130. DOI: 10.1080/00785236.2000. 10409442

MILLS, K. \& D. B. RYVES. 2012. Diatom-based models for inferring past water chemistry in western Ugandan crater lakes. Journal of Paleolimnology, 48 (2): 383-399. DOI: 10.1007/s10933-012-9609-2

MIRACLE, M. R., M. SAHUQUILlO, T. ALFONSO \& M. D. SENDRA. 2012. Les fases clares a l'Albufera: una via per a la seua recuperació. In: La Universitat de València $i$ els seus entorns naturals: 96-99. Universitat de València, València.

MOORE, P. D., J. A. WEBB \& M. E. COLLINSON. 1991. Pollen Analysis. Blackwell Scientific Publications. Oxford.

MORENO, A., B. L. VALERO-GARCÉS, M. JIMÉNEZ SÁNCHEZ, M. J. DOMÍNGUEZ, P. MATA, A. NAVAS, P. GONZÁLEZSAMPÉRIZ, H. STOLL, P. FARIAS, M. MORELLÓN, P. CORELLA, \& M. RICO. 2010. The last deglaciation in the Picos de Europa National Park (Cantabrian Mountains, Northern Spain). Journal of Quaternary Science, 25: 1076-1091. DOI: 10.1002/jqs.1265 PANTALEÓN-CANO, J., R. PÉREZ-OBIOL, E. I. YLL \& J. M. ROURE. 1996. Significado de Pseudoschizaea en las secuencias sedimentarias de la vertiente mediterránea de la Península Ibérica e Islas Baleares. In: B. Ruiz-Zapa- ta (ed.). Estudios palinológicos: 101-105. Universidad de Alcalá, Alcalá de Henares.

PARDO, L. 1942. La Albufera de Valencia. Estudio limnográfico, biológico, económico y antropológico. Instituto Forestal de Investigaciones y Experiencias, 24:1-234.

PHILIPPSEN, B. 2013. The freshwater reservoir effect in radiocarbon dating. Heritage Science 1:24. DOI: $10.1186 / 2050-7445-1-24$

PHILIPPSEN B \& J. HEINEMEIER. 2013. Freshwater reservoir effect variability in northern Germany. Radiocarbon, 55(2-3):1085-101. DOI: $10.1017 / \mathrm{S} 0033822200048001$

PIERA, J. 1983. Poemes de l'orient d'Al-Andalus, Ed. 62. Barcelona.

POQUET, J. M., F. MEZQUITA, J. RUEDA, M. R. MIRACLE. 2008. Loss of Ostracoda biodiversity in Western Mediterranean wetlands. Aquatic conservation: Marine \& Freshwater ecosystems, 18: 280-296. DOI: 10.1002/aqc.831

REED, J. M. 1998. A diatom-conductivity transfer function for Spanish salt lakes. Journal of Paleolimnology, 19: 399-416. DOI: 10.1023/ A:1007934627134

REED, J. M., A. C. STEVENSON \& S. JUGGINS. 2001. A multi-proxy record of Holocene climate change in southwest Spain: the Laguna de Medina, Cádiz. The Holocene, 11: 705-717. DOI: 10.1191/09596830195735

REILlE, M. 1992. Pollen et Spores d'Europe et d'Afrique du nord. Laboratoire de Botanique Historique et Palynologie. Marseille.

REILlE, M. 1995. Pollen et Spores d'Europe et d'Afrique $d u$ Nord (Supplément 1). Laboratoire de Botanique Historique et Palynologie, CNRS. Marseille.

REILLE, M. 1998. Pollen et Spores d'Europe et d'Afrique du nord (Supplément 2). Laboratoire de Botanique Historique et Palynologie, CNRS. Marseille.

REIMER, P. J., M. G. L. BAILLIE, E. BARD, A. BAYLISS, J. W. BECK, C. J. H. BERTRAND, P. G. BLACKWELL, C. E. BUCK, G. S. BURR, K. B. CUTLER, P. E. DAMON, R. L. EDWARDS, R. G. FAIRBANKS, M. FRIEDRICH, T. P. GUILDERSON, A. G. HOGG, K. A. HUGHEN, B. KROMER, G. MCCORMAC, S. MANNING, C. B. RAMSEY, R. W. REIMER, S. REMMELE, J. 
R. SOUTHON, M. STUIVER, S. TALAMO, F. W. TAYLOR, J. VAN DER PLICHT \& C. E. WEYHENMEYER 2004. IntCal04 Terrestrial Radiocarbon Age Calibration, 0-26 cal kyrs BP. Radiocarbon, 46 (3): 1029-1059. DOI: $10.1017 / \mathrm{S} 0033822200032999$

RENBERG, I., R. BINDLER \& M. L. BRÄNNVALL. 2001. Using the historical atmospheric lead-deposition record as a chronological marker in sediment deposits in Europe. The Holocene, 11 (5): 511-516. DOI: 10.1191/ 095968301680223468

REVELLES, J., F. BURJACHS \& B. VAN GEEL. 2016. Pollen and non-pollen palynomorphs from the Early Neolithic settlement of La Draga (Girona, Spain). Review of Palaeobotany and Palynology, 225: 1-20. DOI: 10.1016/j.revpalbo.2015.11.001

ROBLES, F., M. A. COLLADO \& V. BORREDÁ. 1985. Variaciones en la fauna de moluscos en la Albufera de Valencia: implicaciones paleogeográficas. In: Pleistoceno y Geomorfología litoral. Homenaje a Juan Cuerda: 123-133. Universidad de Valencia, Valencia.

RODRIGO, M. A., J. L. ALONSO-GUILLÉN \& I. SOULIÉ-MÄRSCHE. 2010. Reconstruction of the former charophyte community out of the fructifications identified in Albufera de València lagoon sediments. Aquatic Botany, 92: 14-22. DOI: 10.1016/j. aquabot.2009.09.002

RODRIGO, M. A. \& J. L. ALONSO-GUILLÉN. 2013. Assessing the potential of Albufera de València Lagoon sediments for the restoration of charophyte meadows. Ecological Engineering, 60: 445-452. DOI: 10.1016/j. ecoleng.2013.09.041

ROMO, S., M. J. VILLENA, M. SAHUQUILLO, J. M. SORIA, M. GIMENEZ, T. ALFONSO, E. VICENTE \& M. R. MIRACLE. 2005. Response of a shallow Mediterranean lake to nutrient diversion: does it follow similar patterns as in northern shallow lakes?. Freshwater Biology, 50(10): 1706-1717. DOI: 10.1111/j.1365-2427.2005.01432.x

ROSSELLÓ I VERGER, V. M. 1995. L'Albufera de València. Publicacions de l'Abadia de Montserrat, Barcelona.

RUIZ, F., M. L. GONZÁLEZ-REGALADO, J. I. BACETA \& J. M. MUÑOZ, J.M. 2000. Com- parative ecological analysis of the ostracod faunas from low and high-polluted southwestern Spanish estuaries: a multivariate approach. Marine Micropalaeontology, 40: 345-376. DOI: $10.1016 / \mathrm{S} 0377-8398(00) 00048-7$

RUÍZ, J. M. \& P. CARMONA. 2005. La llanura deltaica de los ríos Júcar y Turia y la Albufera de Valencia. In: Geomorfología litoral. Homenaje a V.M. Rosselló. Sanjaume, E. \& J.F. Mateu (eds.): 399-419. Departament de Geografia, Universitat de València, Valencia.

SABATIER, P., L. DEZILEAU, L. BRIQUEU, C. COLIN \& G. SIANI. 2010. Clay minerals and geochemistry record from northwest Mediterranean coastal lagoon sequence: Implications for paleostorm reconstruction. Sedimentary Geology, 228(3): 205-217. DOI: 10.1016/j.sedgeo.2010.04.012

SABATIER, P., L. DEZILEAU, C. COLIN, L. BRIQUEU, F. BOUCHETTE, P. MARTINEZ, G. SIANI, O. RAYNAL \& U. VON GRAFENSTEIN. 2012. 7000 years of paleostorm activity in the NW Mediterranean Sea in response to Holocene climate events. Quaternary Research, 77(1): 1-11. DOI: 10.1016/j. yqres.2011.09.002

SANCHIS IBOR, C. 2001. Regadiu i canvi ambiental a l'Albufera de València. Publicacions de la Universitat de València, València:.

SANTISTEBAN, C., J. MARCO-BARBA \& M. R. MIRACLE. 2009. La evolución Holocena de la Albufera de Valencia. Geogaceta, 46: 99-102.

SIANI, G., M. PATERNE, M. ARNOLD, E. BARD, B. MÉTIVIER, N. TISNERAT \& F. BASSINOT. 2000. Radiocarbon reservoir ages in the Mediterranean Sea and Black Sea coastal waters. Radiocarbon, 42 (2): 271-280. DOI: $10.1017 / \mathrm{S} 0033822200059075$

SORIA, J. M. 2006. Past, present and future of la Albufera of Valencia Natural Park. Limnetica, 25 (1-2): 135-142.

SORIA, J. M., M. R. MIRACLE \& E. VICENTE. 1987. Aporte de nutrientes y eutrofización de la Albufera de Valencia. Limnetica, 3: 227-242.

TRAVERSE, A. 2007. Paleopalynology. Topics in Geobiology, Vol. 28, Springer, Dordrecht, $813 \mathrm{p}$. 
TWEDDLE, J. C., K. J. EDWARDS \& N. R. J. FIELLER. 2005. Multivariate statistical and other approaches for the separation of cereal from wild Poaceae pollen using a large Holocene dataset. Vegetation History and Archaeobotany, 14 (1): 15-30. DOI: 10.1007/s00334005-0064-0

USERA, J., M. FAURA \& Y. ARCO. 1990. Foraminíferos cuaternarios de las fases de colmatación de la Albufera de Valencia. In: VI Jornadas de la Sociedad Española de Paleontología, Libro de resúmenes: 61. Granada.

USERA, J. \& MATEU, G. 1995. Foraminíferos cuaternarios en el Pais Valenciano. In: $E l$ Cuaternario del Pais Valenciano: 245-250. Asociación Española para el Estudio del Cuaternario, Universitat de Valencia.

USERA, J., C. ALBEROLA \& J. M. BRITO. 2006. Foraminíferos de la Albufera de Valencia: Sondeo de "El Palmar". In: XXII Jornadas de la Sociedad Española de Paleontología. Libro de Resúmenes: 193-194. León.

USERA, J., C. ALBEROLA \& J. M. BRITO. 2007a. Foraminíferos holocenos de tres sondeos de la Albufera de Valencia (Valencia, España). In: XII Reunión Nacional de Cuaternario, Libro de Resúmenes: 83-84. Ávila.

USERA, J., C. ALBEROLA \& J. M. BRITO. 2007b. The last foraminiferal association in the costal lagoon of the Albufera of Valencia (Valencia, Spain). In: ISMS07. Simposio Internacional de Ciencias del mar. Simposio GLOBEC-IMBER: 52. Valencia.

USERA, J. \& C. ALBEROLA. 2011. XXVII Jornadas de la Sociedad Española de Paleontología y Simposios de los Proyectos PICG 587 y 596. Libro de Resúmenes: 387-389. Sabadell.

VALDERRAMA, J. C. 1981 The simultaneous analysis of total nitrogen and total phosphorus in natural waters. Marine Chemistry, 10: 109-122. DOI: 10.1016/0304-4203(81) 90027-X

VAN GEEL, B. 1978. A palaeoecological study of Holocene peat bog sections in Germany and The Netherlands, based on the analysis of pollen, spores and macro- and microscopic remains of fungi, algae, cormophytes and animals. Review of Palaeobotany and Palynology, 25: 1-120. DOI: 10.1016/0034-6667 (78)90040-4

VAN GEEL, B. 2001. Non-pollen palynomorphs. In: Tracking Environmental Change Using Lake Sediments, vol 3. Smol, J.P., H.J.B. Birks \& W.M. Last (eds.): 99-119. Kluwer Academic Publishers, Dordrecht. DOI: 10.1007/0-30647668-1

VAN HARTEN, D. 1975. Size and environmental salinity in the modern euryhaline ostracod Cyprideis torosa (Jones, 1850) a biometrical study, Palaeogeography, Palaeoclimatology, Palaeogeography, 17: 35-48. DOI: 10.1016/ 0031-0182(75)90028-0

VAN HOEVE, M. L. \& M. HENDRIKSE (Eds). 1998. A study of non-pollen objects in pollen slides. The types as described by Dr Bas van Geel and colleagues. Utrecht.

VESPER, B. 1972a. Um Problem der Buckelbildung bei Cyprideis torosa (JONES, 1850) (Crustacea, Ostracoda, Cytheridae). Mitteilungen Hamburger Zoologisches Museum und Institut, 68: 79-94.

VESPER, B. 1972b. Zur Morphologie und Ökologie von Cyprideis torosa (Jones, 1850) (Crustacea, Ostracoda, Cytheridae) unter besonderer Berücksichtigung seiner Biometrie. Mitteilungen Hamburger Zoologisches Museum und Institut, 68: 21-77.

VICENTE, E. \& M. R. MIRACLE. 1992. The coastal lagoon Albufera de Valencia Natural Park: an ecosystem under stress. Limnetica, 8: 87-100.

ZARAGOZA PÉREZ, M. 1982. El cultiu tradicional de l'arròs a Silla (Albufera de València). Institut de Filologia Valenciana, València.

ZWOLSMAN, J. J. G., G. W. BERGER \& G. T. M. VAN ECK. 1993. Sediment accumulation rates, historical input, postdepositional mobility and retention of major element and trace metals in salt march sediment of Scheldt estuary. Marine Chemistry, 44: 73-94. DOI: 10.1016/0304-4203(93)90007-B

Con el apoyo de:
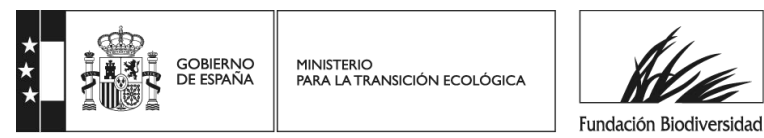